\title{
Review \\ Effects of Gut Metabolites and Microbiota in Healthy and Marginal Livers Submitted to Surgery
}

\author{
Marc Micó-Carnero ${ }^{1,+} \mathbb{D}$, Carlos Rojano-Alfonso ${ }^{1,+}{ }^{\text {, Ana Isabel Álvarez-Mercado }}{ }^{2,3,4} \mathbb{D}^{\text {, Jordi Gracia-Sancho }}{ }^{5,6} \mathbb{D}$, \\ Araní Casillas-Ramírez ${ }^{7,8, \ddagger(\mathbb{D})}$ and Carmen Peralta ${ }^{1, *, \neq(\mathbb{D})}$
}

1 Institut d'Investigacions Biomèdiques August Pi i Sunyer (IDIBAPS), 08036 Barcelona, Spain; mico@clinic.cat (M.M.-C.); rojano@clinic.cat (C.R.-A.)

2 Departamento de Bioquímica y Biología Molecular II, Escuela de Farmacia, Universidad de Granada, 18071 Granada, Spain; analvarezmercado@gmail.com

3 Institut of Nutrition and Food Technology "José Mataix", Center of Biomedical Research, University of Granada, 18016 Granada, Spain

4 Instituto de Investigación Biosanitaria ibs, GRANADA, Complejo Hospitalario Universitario de Granada, 18014 Granada, Spain

5 Liver Vascular Biology Research Group, Barcelona Hepatic Hemodynamic Laboratory IDIBAPS, 03036 Barcelona, Spain; Jordi.gracia@idibaps.org

6 Centro de Investigación Biomédica en Red de Enfermedades Hepáticas y Digestivas (CIBERehd), 08036 Barcelona, Spain

7 Hospital Regional de Alta Especialidad de Ciudad Victoria "Bicentenario 2010", Ciudad Victoria 87087, Mexico; aranyc@yahoo.com

8 Facultad de Medicina e Ingeniería en Sistemas Computacionales de Matamoros, Universidad Autónoma de Tamaulipas, Matamoros 87300, Mexico

* Correspondence: cperalta@clinic.cat

+ These authors equally contributed to this work.

$\ddagger$ These authors equally contributed to this work.

check for updates

Citation: Micó-Carnero, M.; RojanoAlfonso, C.; Álvarez-Mercado, A.I.; Gracia-Sancho, J.; Casillas-Ramírez, A.; Peralta, C. Effects of Gut Metabolites and Microbiota in Healthy and Marginal Livers Submitted to Surgery. Int. J. Mol. Sci. 2021, 22, 44. https:// dx.doi.org/10.3390/ijms22010044

Received: 13 November 2020 Accepted: 20 December 2020 Published: 22 December 2020

Publisher's Note: MDPI stays neutral with regard to jurisdictional claims in published maps and institutional affiliations.

Copyright: (c) 2020 by the authors. Licensee MDPI, Basel, Switzerland. This article is an open access article distributed under the terms and conditions of the Creative Commons Attribution (CC BY) license (https: / / creativecommons.org/ licenses/by/4.0/).

\begin{abstract}
Microbiota is defined as the collection of microorganisms within the gastrointestinal ecosystem. These microbes are strongly implicated in the stimulation of immune responses. An unbalanced microbiota, termed dysbiosis, is related to the development of several liver diseases. The bidirectional relationship between the gut, its microbiota and the liver is referred to as the gut-liver axis. The translocation of bacterial products from the intestine to the liver induces inflammation in different cell types such as Kupffer cells, and a fibrotic response in hepatic stellate cells, resulting in deleterious effects on hepatocytes. Moreover, ischemia-reperfusion injury, a consequence of liver surgery, alters the microbiota profile, affecting inflammation, the immune response and even liver regeneration. Microbiota also seems to play an important role in post-operative outcomes (i.e., liver transplantation or liver resection). Nonetheless, studies to determine changes in the gut microbial populations produced during and after surgery, and affecting liver function and regeneration are scarce. In the present review we analyze and discuss the preclinical and clinical studies reported in the literature focused on the evaluation of alterations in microbiota and its products as well as their effects on post-operative outcomes in hepatic surgery.
\end{abstract}

Keywords: microbiota; liver transplantation; partial hepatectomy; liver surgery; ischemia-reperfusion

\section{Introduction}

Liver transplantation (LT) faces an urgent problem due to the shortage of liver grafts available for transplant. With the aim of resolving this problem, the criteria for discarding liver grafts have been changed. Thus, organs with diseases such as steatosis and positive hepatitis B or C have been used in LT [1]. Liver steatosis is a key factor when evaluating donor livers because of the high prevalence (30\% in cadaveric and $20 \%$ in living donors) of negatively affecting recipient outcomes [1]. Thus, non-alcoholic fatty liver disease (NAFLD) is a common cause of liver rejection [2]. However, it is known that these types of 
livers are less functional and more sensitive to the injurious effects induced by ischemiareperfusion $(I / R)$, which is associated with graft dysfunction or primary non-function after transplantation $[1,3]$. Also, it should be noted that $\mathrm{I} / \mathrm{R}$ negatively affects the regenerative capacity of the liver after a partial hepatectomy $(\mathrm{PH})$, which might result in liver failure and poor post-operative outcomes [4].

In LT and PH surgery, the damage induced by I/R (which is exacerbated by diseases such as steatosis or cirrhosis) originates from the loss of blood supply during ischemia and its reestablishment during the reperfusion phase. This initiates a cascade of pathological features leading to an increase of reactive oxygen species (ROS), cytokines and neutrophil accumulation, resulting in inflammation, regenerative failure and cell death [5]. Since I/ $R$ is an inherent part of the surgical process in hepatic resections and LT [6], the numerous studies reported in the literature have mainly focused on procedures directed at the liver itself to reduce the injurious effects of ROS through the administration of antioxidants [7], to reduce neutrophil accumulation through treatment with antibodies anti-P-selectin or antiintercellular adhesion molecule 1 (anti-ICAM) [8,9] or to regulate the activity or levels of some cytokines involved in the inflammatory process, such as tumor necrosis factor (TNF) or interleukin-6 (IL-6) [10]. However, the hepatic I/R associated with hepatic resections and LT (especially in the presence of liver disease) remains an unresolved problem in clinical practice. In our view, alternative strategies that are not focused exclusively on the liver, and studies to evaluate options other than the liver as the main target for reducing the mechanisms responsible for the pathologies associated with hepatic resection and LT are required.

\section{Relevance of the Gut-Liver Axis}

Given the observations mentioned above, the current review will focus on the gutliver axis (a consequence of the close anatomical and functional bidirectional interaction between the gastrointestinal tract and liver, primarily through the portal circulation) [11] in hepatic surgery, and will investigate the potential existence of a relationship between liver surgery and changes in the gut microbiota [12,13]. Indeed, some studies suggest that alterations in the gut microbiota might be responsible for the post-operative outcomes in different pathologies, which require the presence of a relationship between the intestine and the liver. Such is the case with the clinical surgical procedures of hepatic resections and LT [14,15].

The gut microbiota (GM) is a microbial community living in symbiosis both between constituents and with the human. The majority of its species are commensals, mainly from the Firmicutes and Bacteroidetes phyla, but there are also other phyla such as Proteobacteria or Actinobacteria $[16,17]$.

Currently, many findings have shown alterations to GM in pathological conditions such as cardiovascular disease [18,19], cirrhosis [20], insulin resistance [21,22] or inflammatory bowel disease [23]. These alterations in GM might negatively affect recovery time and quality in patients, in addition to the effects of the different treatments applied. To elucidate the relevance of GM, investigations aimed at evaluating the signaling pathways involved in the gut-liver axis have been performed $[4,17,24]$. If there is dysbiosis, the microbiota is not properly balanced, thereby inducing an increase in intestinal permeability. If the intestinal barrier is affected, products present in the gut can reach the liver, including some that are toxic to the organism resulting in hepatic inflammation and the consequent development from simple steatosis to non-alcoholic steatohepatitis (NASH) $[25,26]$. This progression has been related with cytotoxicity resulting from the increases in fecal bile acids (BAs) and primary/secondary BA ratio, plasma and liver BA levels and plasma lipopolysaccharides (LPS) $[25,27,28]$. NAFLD patients showed fewer amounts of Bacteroidetes, Ruminococcaceae and Faecalibacterium prausnitzii and greater amounts of Prevotella, Porphyromas, Lactobacillus, Escherichia, and Streptococcus than healthy subjects [26,29].

In cirrhotic animals, an increase in the Firmicutes and Actinobacteria compared with control mice has been described [30]. However, increased levels of Veillonella, Megasphaera, 
Dialister, Atopobium, and Prevotella has been observed in cirrhotic patients [31]. Preclinical results indicated that HFD diet and intestinal Gram-negative bacteria resulted in liver fibrogenesis [32]. However, LPS reduction and intestinal tight junctions (TJs) restoration might be a therapeutic strategy for the treatment of fibrosis in NASH [33].

The gradual alcoholic liver disease (ALD) at early disease stages is related to dysbiosis and increased microbial translocation. The bacterial species related with such changes include Streptococcus, Shuttleworthia, and Rothia [34]. In long-time alcohol consumers, it has been described as a rise of Gram-negative bacteria, which cause endotoxemia and hyper-activation in the immune system [35]. The diminution in the Roseburia abundance is related to alcohol consumption in the human cohort [36], wheras Roseburia administration in an experimental ALD model improves hepatic steatosis and inflammation [36].

Chen et al. [37] describes genetic and microbial associations to plasma and fecal BA concentrations and composition in obese patients and establish their relationships with liver fat. The authors reported several microbial species that clustered together and showed strong positive correlations with secondary BA and negative correlations with primary BA entities. These included microbial species capable of mediating the conversion of primary BAs into secondary ones such as Eubacterium hallii [38] or Ruminococcus torques [39] and Ruminococcus sp_5_1_39BFAA [40], positively correlated with the levels of secondary/primary BA ratio in plasma. The study reported by Kurilshikov et al. [40] presents the largest metagenome-based association on plasma metabolism and microbiome relevance to diet, inflammation and cardiovascular disease (CVD) risk in obese patients. The authors indicated that Ruminococcus_5_1_39BFAA were associated to liver fat content in obese patients. Moreover, the amount of the anti-NAFLD species Faecalibacterium prausnitzii [41] is negatively correlated with multiple BA entities and hepatic fatty infiltration as well as intestinal and adipose tissue inflammation.

Given all the data mentioned above, alterations in gut metabolites and microbiota are involved in the pathogenesis and progression of NAFLD. In addition, gut microbial composition and function varies between individuals in different liver diseases.

The current review will analyze and discuss the preclinical and clinical data reported in the literature about potential alterations in the microbiota and its products, and their effect on post-operative outcomes in different types of liver submitted to either hepatic resection or LT. Whether the intestinal dysbiosis or alterations in products derived from the microbiota are a cause or a consequence of liver damage in surgical conditions is of both scientific and clinical interest [24] and will also be discussed. This is because the liver might receive products derived from the gut microbiota, such as short-chain fatty acids (SCFAs), LPS, secondary BAs and amino acids (AAs). The regulation of these products, in which the liver is involved, is important to keep an organism healthy [12]. On the other hand, alterations in such products might negatively affect the quality of transplanted livers and post-operative outcomes (Figure 1) [42]. The mechanisms involved in alterations of the gut microbiota, as well as regulation of the same by different treatments will also be evaluated and discussed. This could contribute to the design of appropriate preclinical models of surgery and the establishment of new strategies that might be useful in the clinical practice of hepatic resections and LT. 


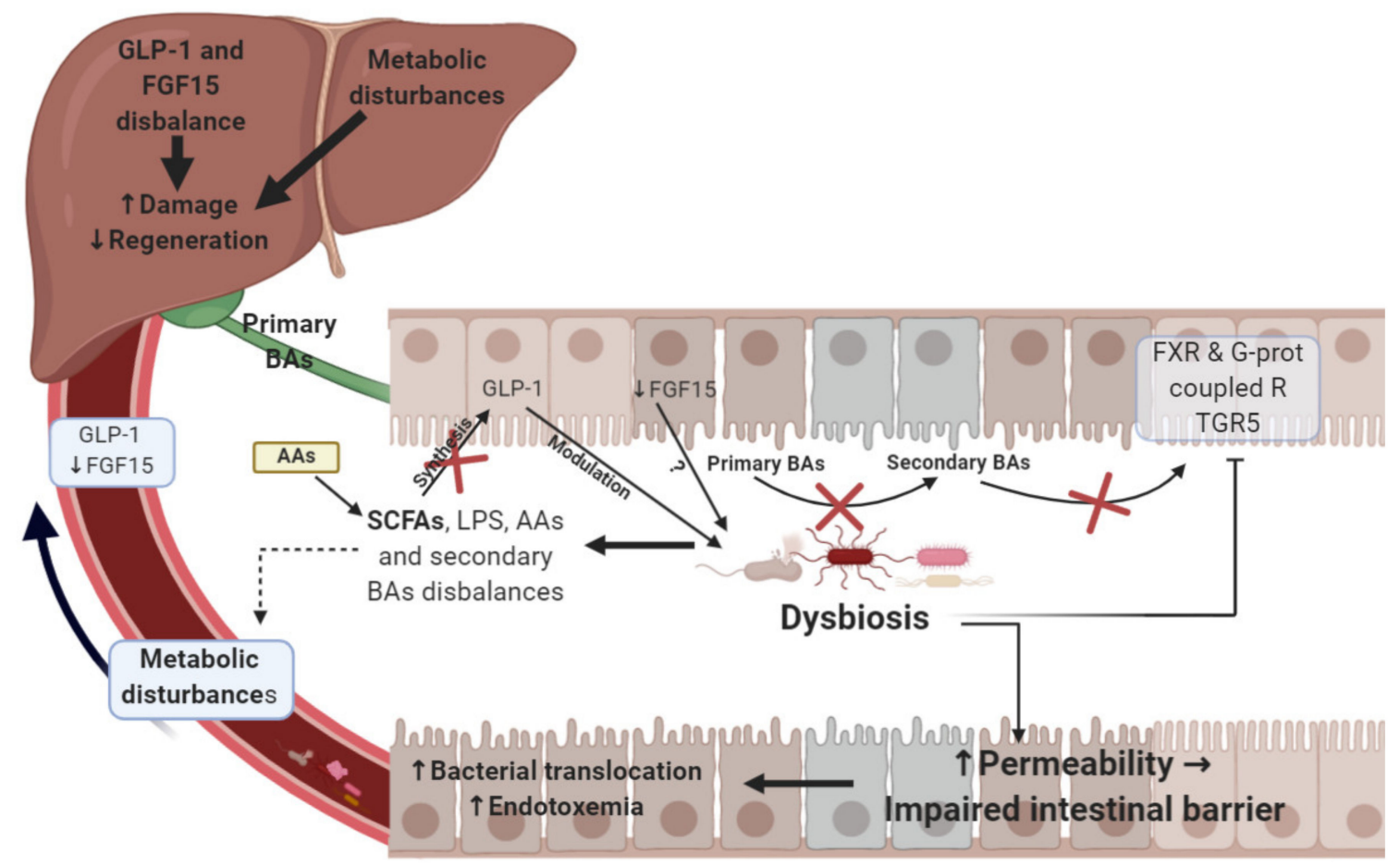

Figure 1. Association between gut microbiota and liver function in liver surgery. Gut dysbiosis leads to an imbalance in microbial metabolites such as SCFAs, LPS or secondary BAs, thus provoking metabolic disturbances and affecting GLP-1 and FGF15 synthesis or FXR and G-protein coupled receptor TGR5 signaling. All of this may increase liver damage and decrease liver regeneration ability. Dysbiosis also seems to alter gut permeability, inducing damaging effects on the intestinal barrier and causing bacterial translocation and endotoxemia. Gut bacteria also provide amino acids to the host and can alter their bioavailability. In addition, amino acids act as precursors for the synthesis of metabolic end products produced by the microbiota such as SCFAs. $\uparrow:$ Increase; $\downarrow$ : Decrease; AAs: Amino acids; BAs: Bile acids; FXR: Farnesoid X receptor; FGF15: Fibroblast growth factor 15; GLP-1: Glucagon-like peptide 1; LPS: Lipopolysaccharides; R TGR5: Receptor of Takeda G protein-coupled receptor 5; SCFAs: Short-chain fatty acids.

\section{Relationship between Liver Transplantation and Gut Microbiota}

Numerous studies have demonstrated that gut dysbiosis is one of the main contributors to end-stage liver disease progression, associated with its severity, and morbidity and mortality rates $[17,43,44]$. Nevertheless, its role in patients following LT remains poorly understood.

The microbiota seems to play an important role in post-operative outcomes according to data reported by many authors [45]. However, it has been suggested that post-surgery prognosis depends on multiple factors such as ischemia-reperfusion injury [46], immunosuppressive drugs [47] or the appropriateness of matching based on donor-organ-recipient variables [48].

The gut microbiota acts by metabolizing bile salts with the aim of neutralizing their toxicity, transforming primary bile acids into secondary ones, thereby modifying the size and composition of the bile acid pool secreted by the liver [49]. BAs contribute to the activation of nuclear receptor, FXR and a membrane $G$ protein-coupled receptor, Takeda G protein-coupled receptor 5 (TGR5) in the ileum [17,50,51]. Gut microbiota dysbiosis down regulates the synthesis of these receptors, inducing bacterial translocation and bacterial overgrowth, especially of gram-negative organisms and the perpetuation of gut permeability [12], contributing to increases in LPS, which might activate the nuclear factor kappa-light-chain-enhancer of activated B cells (NFKB) [52] through toll-like receptors (TLRs) and nod-like receptors (NLRs). All of this leads to the production of inflammatory cytokines and chemokines that enter the portal circulation, resulting in inflammation and liver disease progression $[53,54]$. The involvement of NFK $\beta$ in hepatic I/R is well 
known [55]. Moreover, some secondary BAs produced by the microbiota as deoxycholic acid (DCA) and lithocholic acid (LCA) may regulate the immune system by binding to TGR5 [56]. These secondary BAs may ultimately inhibit NFKB production, thus reducing inflammatory pathways [57]. As it has been mentioned before, dysbiosis causes an alteration in the levels of secondary BAs among which we find DCA and LCA, which could induce inflammation and negatively affect the immune system.

Due to the protective role that FXR and TGR5 exert on liver disease progression, their activation has been proposed as a therapy for liver diseases, with positive results reported in the treatment of NASH [37,58]. More recently, FXR activation via FGF15 has been identified as a way to improve outcomes after brain-dead (BD) donor LT of steatotic and non-steatotic grafts in rats and indeed, BD induced intestinal damage and downregulation of FXR and the resulting reduction in intestinal FGF15 was associated with low hepatic FGF15 levels, liver damage and regenerative failure. FGF15 administration to BD donors increased hepatic fibroblast growth factor receptor-4 and its co-receptor klotho-beta (FGFR4-KLB), reduced the cytochrome P450 7A1 (CYP7A1) enzyme and normalized BA levels. This was associated with protection against the intestinal damage induced by BD [59]. In steatotic grafts from donation after circulatory death (DCD) donors, FGF15 is not involved in damage or proliferation whereas it protected against BA accumulation, damage and regenerative failure in non-steatotic LT from DCDs [60]. Further studies will be required to determine whether the deficiencies in FGF15 generated by the intestine might induce changes in microbiota or related products and what the potential effects of such changes on the liver and post-operative outcomes after LT are. Nevertheless, this possibility should not be discarded. Indeed, some new advances have shown a relationship between FXR, microbiota and TGR5. The activation of FXR signaling by the FXR agonist, fexarmine (FEX) promoted the increase in LCA produced by the gut bacteria. As LCA is a natural agonist of TGR5, amounts in LCA resulted in the activation of the TGR5 signaling pathway to improve hepatic metabolism [61,62].

In line with this, in preclinical models of steatotic and non-steatotic LT from DCD, it has been observed that alterations in hepatic glucagon-like peptide (GLP-1), which is derived from the intestine, negatively affected post-operative outcomes [63]. The possibility that such alterations might induce changes in the microbiota should not be dismissed. Indeed, it has been indicated that GLP-1 can modulate the gut microbiota composition in both simple obese and diabetic obese subjects [64]. In addition, another preclinical study indicates that an SCFA such as propionate induces GLP-1 synthesis [65]. Thus, given that the microbiota metabolizes SCFAs (which regulate GLP-1 synthesis), it is expected that a dysregulation of the microbiome might negatively affect SCFA and consequently GLP-1 in LT, which has not been reported, to date.

It is well known that in physiological conditions, commensal bacteria are able to produce metabolites such as SCFAs (especially butyrate), which are essential for the health of enterocytes and thus for the permeability of the gut barrier [12]. Although different reports indicate that SCFA exert pro-inflammatory effects and active immune system [66,67], this does not seem to be the case in liver transplantation. Indeed, previous clinical studies in liver transplantation indicate that SCFAs reduce hepatic ischemia-reperfusion injury without adverse effects on the immune system $[12,68]$. This is in line with different reports indicating that SCFA have anti-inflammatory and immunosuppressive functions [12,68-70]. Thus, SCFAs have been shown to reduce NFKB gene expression, ameliorating macrophage activation and to mediate systemic adaptive immune responses by inhibiting cytokine production, and the activation of $\mathrm{T}$ cells, while activating regulatory $\mathrm{T}$ cells (Treg) [12,52]. It is well known that in liver transplant recipients, the reduction in inflammatory response is required to reduce the hepatic ischemia-reperfusion injury and that immune response needs to be suppressed to protect the transplanted liver from rejection [71]. Therefore, in addition to the problems associated with the alterations in the microbiota itself, microbiota dysregulation may cause alterations in the production of SCFAs [72], affecting the immune 
system and increasing its activity, which might result in inflammation and a heightened risk of graft rejection.

As it has been explained above, amino acids have an important role in gut-liver axis. In the case of LT, the amino acid glutamine (Gln) has been described as a potential protector of the intestinal barrier permeability and the immune system function. Gln induces enterocyte proliferation, inhibits bacterial translocation to the liver and exerts anti-inflammatory and anti-apoptotic effects [73-75]. Similar effects have been described with the use of branched-chain amino acids (BCAAs), which may help to regulate the immune system in LT [76,77]. Moreover, it has been suggested that the amino acids pool may modify the diversity of the gut microbiome [78] but further clinical and preclinical studies will be required to characterize the types of bacteria affected by such amino acids.

Bacterial infections are remarkably prevalent in liver-transplant recipients (LTRs). According to two clinical studies performed by Echaniz et al. $(n=152)$ and Losada et al. ( $n=149$ ), approximately $70 \%$ of LTRs present with post-operative infections, between $34 \%$ and $50 \%$ of which are bacterial $[79,80]$. According to other studies, infections caused by gram-negative bacteria are the most common after LT [77], promoting inflammation due to their LPS production ability.

As mentioned above, the role of the microbiota in the gut-liver axis after LT has not yet been fully elucidated. Indeed, some recent clinical studies show no significant microbiota differences in the early post-transplantation stage (seven days post-LT) nor in recipients with acute-cell rejection (ACR) or post-LT bloodstream infections [81,82]. On the other hand, many other clinical and preclinical studies differ from these data, supporting the idea that ischemia-reperfusion injury associated with liver surgery may induce changes in the microbiota, affecting inflammation or liver regeneration [4]. Moreover, some data indicate that the gut barrier can be compromised during LT, affecting gut microbiota. The results from these authors indicate that the microbiota is also modified in ACR. The results of some preclinical (Table 1) and clinical studies (Table 2) are shown below.

Table 1. Preclinical studies in liver transplantation (LT).

\begin{tabular}{|c|c|c|c|}
\hline Study & Surgery (DCD/BD) & Recipients Characteristics & Alteration Post-LT \\
\hline Xie et al. (2011) [83] & OLT without DCD/BD & $\begin{array}{l}\text { Normal SD rats (donors) and } \\
\text { normal SD or SD with cirrhosis } \\
\text { (recipients). } \\
\text { Groups: } \\
\text {-LN ( } n=12 ; 6 \text { transplanted rats) } \\
\text {-LTC ( } n=14 ; 7 \text { transplanted rats) }\end{array}$ & $\begin{array}{l}\uparrow \text { endotoxin, BT and bacteria } \\
\text { number in LTC rats. } \\
=\text { Lactobacilli, Bacteroides and } \\
\text { Enterobacteria between groups. } \\
\uparrow \text { MUC } 2 / 3 \text { and TLR } 4 \text { in } \\
\text { LTC rats. } \\
\text { Slight rejection and periportal } \\
\text { inflammatory cell infiltration } \\
\text { in both LN and LTC rat }\end{array}$ \\
\hline Xie et al. (2012) [84] & OLT without DCD/BD & $\begin{array}{l}\mathrm{L} \text { and } \mathrm{BN} \text { rats (donors) and } \mathrm{BN} \text { rats } \\
\text { (recipients). } \\
\text { Groups: } \\
\text {-BN rats transplanted from } \mathrm{L} \text { rats } \\
\text { ( } n=12 ; 6 \text { transplanted } \mathrm{BN} \text { rats) } \\
\text {-BN rats transplanted from } \mathrm{BN} \text { rats } \\
\text { ( } n=12 ; 6 \text { transplanted } \mathrm{BN} \text { rats) }\end{array}$ & $\begin{array}{l}\uparrow \text { endotoxin and BT to the } \\
\text { liver with AR } \\
\uparrow \text { Bacteroides associated to AR } \\
=\text { Clostridium leptum, } \\
\text { Enterobacteriaceae and } \\
\text { Lactobacillus after } 1-2 \text { weeks } \\
\text { post-LT } \\
\text { Better hepatic architecture in } \\
\text { isograft group } \\
\uparrow \text { Liver function index in } \\
\text { allograft group. }\end{array}$ \\
\hline
\end{tabular}


Table 1. Cont.

\begin{tabular}{|c|c|c|c|}
\hline Study & Surgery (DCD/BD) & Recipients Characteristics & Alteration Post-LT \\
\hline Ren et al. (2014) [85] & OLT without DCD/BD & $\begin{array}{l}\mathrm{L} \text { and DA rats (donors) and } \mathrm{L} \text { rats } \\
\text { (recipients). } \\
\text { Groups: } \\
\text {-NR: OLT from L rats to L rats ( } n= \\
\text { 18; } 9 \text { transplanted rats) } \\
\text {-AR: OLT from DA } \\
\text { (specific-pathogen free rats) rats to } \\
\text { L rats. ( } n=18 ; 9 \text { transplanted rats) }\end{array}$ & $\begin{array}{l}\downarrow \text { Faecalibacterium prausnitzii } \\
\text { and Lactobacillus during AR } \\
\uparrow \text { Clostridium bolteae } \\
\text { during AR } \\
\text { Altered intestinal integrity } \\
\uparrow \text { endotoxin } \\
\uparrow \text { hepatic injury in AR rats }\end{array}$ \\
\hline Xie et al. (2014) [86] & OLT without DCD/BD & $\begin{array}{l}\mathrm{L} \text { (donors) and } \mathrm{BN} \text { rats (recipients). } \\
\text { Groups: } \\
\text { Allograft group ( } n=16 ; 8 \\
\text { transplanted rats) } \\
\text { Antibiotic group ( } n=16 ; 8 \\
\text { transplanted rats) } \\
\text { Probiotic group ( } n=16 ; 8 \\
\text { transplanted rats) }\end{array}$ & $\begin{array}{l}\downarrow \text { endotoxemia in } \\
\text { the antibiotic } \\
\uparrow \text { Lactobacillus, C. leptum and } \\
\text { Bifidobacterium in the } \\
\text { probiotic group } \\
=\text { Bacteroides in all groups at } 7 \\
\text { and } 14 \text { days after LT } \\
\downarrow \text { Necrosis, inflammation and } \\
\text { AST in the antibiotic and } \\
\text { probiotic groups }\end{array}$ \\
\hline
\end{tabular}

$\uparrow:$ Increase; $\downarrow$ : Decrease; AR: Acute rejection; AST: Aspartate transaminase; BN: Brown Norway; BT: Bacterial Translocation; L: Lewis; LT: Liver transplantation; LTC: Liver transplantation in cirrhotic receptors; LN: Liver transplantation in normal receptors; MUC2: Mucin 2; MUC3: Mucin 3; NR: Non-rejection group; OLT: Orthotropic liver transplant; SD: Sprague Dawley; TLR4: Toll-like receptor 4.

The results obtained in preclinical models of LT (none featuring BD or DCD conditions) [83-86], indicate that the pathological conditions of recipients (for example, cirrhosis) might increase the total numbers of bacteria, and endotoxins, bacterial translocation (BT) and alterations in some markers of intestinal damage, including mucins or TLRs. However, no apparent alterations in the microbiota phyla were observed in recipients, either with normal or cirrhotic livers.

In both studies comparing results of LT isografts and allografts [84,85], endotoxemia, $\mathrm{BT}$, and both intestinal and hepatic damage were all more evident in allografts than in isografts, along with increased Bacteroides. On the other hand, differences in the alterations, regarding the type of bacteria, were observed in both studies. This was the case with, for example, Lactobacillus and Bacteroides. In our view, this might be explained by differences in the duration of the anhepatic phase. Indeed, the ischemia times were similar in both studies (1 $\mathrm{h}$ and 48-50 $\mathrm{min}$ in Xie [84] and Ren [85], respectively). In addition, neither immunosuppressive drugs nor antibiotics were used in either study. However, the differences between the studies might be explained at least partially by differences in the anhepatic phase duration (15-30 $\mathrm{min}$ and $25 \mathrm{~min}$ in Xie [84] and Ren [85], respectively). This proposition is supported by the relevance of intestinal congestions occurring during the anhepatic phase [87], which might induce changes in the gut microbiota depending on the damaging effects on the intestine, which, in turn, depend on the phase duration.

Other studies looking at the administration of either antibiotics or probiotics in allograft LT indicate that the number of Lactobacillus and C. leptum and Bifidobacterium spp was greater in the probiotic group than in the antibiotic and allograft groups. By histological analysis, necrosis and inflammation were lower in the antibiotic group than in the allograft group. However, in relation to the hepatic damage, only AST was reduced in probiotic and antibiotic groups as compared with the allograft group [86].

As mentioned above, all results are derived from LT performed in the absence of BD or DCD, which is to say, in very different surgical conditions than those occurring in clinical practice, it should be borne in mind that BD or DCD induction might induce changes in the number and type of microbial phyla as well as in their products. BD and DCD induce important hemodynamic changes, warm hepatic ischemia, hypoperfusion in the mesenteric microcirculation and reduced hepatic blood flow [88-90], resulting in important alterations of the mediators generated in the intestine, intestinal damage, dysregulation in BAs and 
inflammation [59]. All of this negatively affects liver grafts. In addition, given the results shown in the table, all liver grafts were derived from healthy rats. It follows that, in the studies by Xie and Ren, the liver grafts were not subjected to cold ischemia, whereas it is well known that 6-8 h of cold ischemia is commonly used in clinical practice [91]. Therefore, much needs to be done before experimental results can be transferred into clinical practice. Indeed, we still do not know precisely how steatosis (type, grade and so on) affects the gut microbiota, post-operative results or graft survival. In addition, the success or dysfunction of liver grafts may be affected by other factors including donor age [92], cold ischemia times [93], the length of intensive care stays [94] and the type of donor (whether BD or DCD) $[88,89]$. The effect of such conditions on gut microbiota remains to be elucidated. All these limitations demand that new preclinical studies in the field of LT must be performed in experimental models as close as possible to real clinical conditions (i.e., cadaveric and living donors, proper ischemia times, presence of steatosis, different ages of donors, and different types of death). The effectiveness of a given strategy could differ depending on any of the above surgical conditions. Consequently, protective strategies that work under some conditions may be ineffective or even deleterious when those conditions change.

Table 2. Clinical studies in LT.

\begin{tabular}{|c|c|c|c|c|c|}
\hline Study & $\begin{array}{c}\text { Surgery } \\
\text { (DCD/BD) }\end{array}$ & Population & IS & Antibiotics & Alterations Post-LT \\
\hline $\begin{array}{l}\text { Wu et al. (2012) } \\
\text { [72] }\end{array}$ & No specified & $\begin{array}{l}-28 \text { healthy volunteers } \\
-51 \text { cirrhotic patients } \\
-111 \text { liver-transplanted } \\
\text { patients with cancer or } \\
\text { cirrhosis. }\end{array}$ & $\begin{array}{l}-\mathrm{GC} \\
-\mathrm{MPA} \\
-\mathrm{CNIs}\end{array}$ & No antibiotics use & $\begin{array}{l}\downarrow \text { Eubacteria, } \\
\text { Bifidobacterium spp., } \\
\text { Faecalibacterium } \\
\text { prausnitzii and } \\
\text { Lactobacillus spp. } \\
\text { in LTR. } \\
\uparrow \text { Enterobacteriaceae and } \\
\text { Enterococcus spp. } \\
\text { in LTR } \\
\text { Enterococcus spp. } \\
\text { showed a tendency to } \\
\text { restore to } \\
\text { normal levels } \\
\uparrow \text { Plasma endotoxin, } \\
\text { IL-6 and fecal sIgA in } \\
\text { cirrhotic patients but } \\
\text { not in LTR }\end{array}$ \\
\hline $\begin{array}{l}\text { Lu et al. (2013) } \\
\text { [95] }\end{array}$ & No specified & $\begin{array}{l}12 \text { OLT recipients with } \\
\text { liver failure from } \\
\text { hepatitis B virus (HBV) } \\
\text { liver cirrhosis }\end{array}$ & $\begin{array}{l}\text { Different for each } \\
\text { patient }\end{array}$ & No antibiotics use & $\begin{array}{l}\downarrow \text { microbial diversity } \\
\text { in some patients } \\
\text { Presence of infection } \\
\text { in some patients }\end{array}$ \\
\hline $\begin{array}{l}\text { Bajaj et al. } \\
\text { (2017) [96] }\end{array}$ & No specified & $\begin{array}{l}45 \text { LT patients } \\
\text { with cirrhosis }\end{array}$ & $\begin{array}{l}\text {-Steroids } \\
\text {-MPA } \\
\text {-Tacrolimus }\end{array}$ & TMP-SMX & Dysbiosis after LT \\
\hline
\end{tabular}


Table 2. Cont.

\begin{tabular}{|c|c|c|c|c|c|}
\hline Study & $\begin{array}{c}\text { Surgery } \\
\text { (DCD/BD) }\end{array}$ & Population & IS & Antibiotics & Alterations Post-LT \\
\hline $\begin{array}{l}\text { Kato et al. } \\
\text { (2017) [81] }\end{array}$ & $\begin{array}{l}\text { Deceased and } \\
\text { living donor }\end{array}$ & $\begin{array}{l}38 \text { LT patients } \\
\text { (exclusion of } \\
\text { patients with } \\
\text { fulminant hepatitis } \\
\text { or with a previous } \\
\text { transplant) }\end{array}$ & $\begin{array}{l}\text {-Tacrolimus } \\
\text {-MPA } \\
\text {-Steroids }\end{array}$ & $\begin{array}{l}13 \text { received broad } \\
\text { spectrum of } \\
\text { antibiotics }\end{array}$ & $\begin{array}{l}\downarrow \text { microbiota diversity } \\
\text { associated with high } \\
\text { ESLD scores and ACR } \\
\uparrow \text { Bacteroides, } \\
\text { Enterobacteriaceae, } \\
\text { Streptococcaceae and } \\
\text { Bifidobacteriaceae } \\
\downarrow \text { Enterococcaceae, } \\
\text { Lactobacillaceae, } \\
\text { Clostridiaceae, } \\
\text { Ruminococcaceae and } \\
\text { Peptostreptococcaceae }\end{array}$ \\
\hline $\begin{array}{c}\text { Sun et al. (2017) } \\
\text { [97] }\end{array}$ & No specified & $\begin{array}{l}9 \text { LT with ESLD } \\
(4 \text { patients with } \\
\text { cirrhosis and } 5 \\
\text { with HCC) } \\
15 \text { healthy controls }\end{array}$ & $\begin{array}{l}\text {-Tacrolimus } \\
\text {-MP }\end{array}$ & Cephalosporin & $\begin{array}{l}\downarrow \text { Actinobacillus, } \\
\text { Escherichia, and } \\
\text { Shigella after LT } \\
\uparrow \text { Micromonosporaceae, } \\
\text { Desulfobacterales, } \\
\text { the Sarcina genus of } \\
\text { Eubacteriaceae, and } \\
\text { Akkermansia }\end{array}$ \\
\hline $\begin{array}{l}\text { Bajaj et al. } \\
\text { (2018) [15] }\end{array}$ & Deceased donors & $\begin{array}{l}\text { - } 40 \text { patients with } \\
\text { cirrhosis } \\
\text {-Patients are their } \\
\text { own controls }\end{array}$ & $\begin{array}{l}\text {-Steroids } \\
\text {-MPA } \\
\text {-Tacrolimus }\end{array}$ & TMP-SMX & $\begin{array}{l}\uparrow \text { bacterial action } \\
\text { after LT }\end{array}$ \\
\hline $\begin{array}{c}\text { Lu et al. (2019) } \\
\text { [42] }\end{array}$ & No specified & $\begin{array}{l}\text {-Healthy controls } \\
(n=61) \\
\text {-LTR with HCC ( } n \\
=90): 42 \text { with LTA } \\
\text { and } 48 \text { with LTN }\end{array}$ & -FK506 tacrolimus & $\begin{array}{l}\text { No antibiotic use } \\
\text { in the } 12 \text { weeks } \\
\text { prior to enrollment }\end{array}$ & $\begin{array}{l}\downarrow \text { fecal microbiome } \\
\text { diversity in recipients } \\
\text { in the LTA group } \\
\uparrow \text { opportunistic } \\
\text { pathogens such as } \\
\text { Klebsiella and } \\
\text { Escherichia/Shigella in } \\
\text { all LTR } \\
\downarrow \text { beneficial } \\
\text { butyrate-producing } \\
\text { bacteria in LTR }\end{array}$ \\
\hline
\end{tabular}

$\uparrow:$ Increase; $\downarrow$ : Decrease; ACR: Acute cell rejection; CNIs: Calcineurin Inhibitors; ESLD: End-stage liver disease; GC: Glucocorticoids; HCC: Hepatocellular carcinoma; IL: Interleukin; IS: Immunosuppression; LTA: Abnormal liver function; LTN: Normal liver function; LTR: Liver transplant recipient; MP: Methylprednisolone; MPA: Mycophenolate; sIgA: Secretory IgA; TMP-SMX: Trimethoprim-sulfomethoxazole.

According to the different clinical studies shown in the table, LT patients have dysbiosis during the initial post-surgery period [15,42,72,81,95-97]. Nevertheless, the data indicate that most bacteria are completely recovered after one month, which suggests that pre-transplant gut microbiota changes in patients with cirrhosis or end-stage liver disease may have a more powerful influence on dysbiosis than the LT itself. This suggestion could be supported by the data obtained by Xie et al. (2011) [83], who observed that changes in the microbiota balance were higher in rats with cirrhosis and recipients of cirrhotic liver than in rats with no pre-existing pathology. However, in our view, knowledge of the status of gut microbiota in the patient immediately before implantation of the liver graft and comparison with post-LT analysis will be required before it can be concluded that the surgery itself does not play a key role in alterations in the gut microbiota. According to the studies reported above, some data could be contradictory regarding alterations in the type of bacteria. This might be explained, at least partially, by different immunosuppression regimens as well as by the type and dose of antibiotic used. Indeed, differential effects 
of immunosuppressive drugs such as tacrolimus or mycophenolate (MPA) on the gut microbiota have been observed [98].

In line with this, mice treated with a combination of different immunosuppressive drugs show an increase of either E. Coli pathogenic bacteria or the Clostridium sensu stricto genus, modifying gut microbiota balance [98]. Moreover, other preclinical studies report that cyclosporine could ameliorate graft function and avoid graft rejection by decreasing some Clostridium clusters and Enterobacteriaceae pathogenic bacteria and increasing Faecalibacterium prausnitzii beneficial bacteria [99]. Finally, Jiang JW et al. demonstrate that gut microbial disbalance can be due not only to different immunosuppressive agents, but also to the different doses applied. Thus, a middle dose of tacrolimus-FK506 maintains a good graft function, avoids intestinal disruption and maintains a stable microbiota balance. However, this was not the case for a high dose of FK506 since it has been associated with an increase of plasma endotoxin levels [100]. A small clinical study described the relationship between FK506 and microbiota, reporting that the use of FK506 in the short-term increased intestinal permeability in a dose-dependent manner [101]. On the other hand, another clinical study described that the use of FK506 and cyclosporine over 2-3 years have not had an effect on intestinal permeability or endotoxemia [102]. Despite that the studies performed in humans are limited, the data suggest that immunosuppression has an effect on microbiota only in the early post-LT, but further studies are needed to confirm these data.

Similarly, according to results reported in the table, patients received types of antibiotics [15,42,72,81,95-97]. Moreover, the antibiotic dose used in transplant recipients varied, which might result in different microbiota populations [103]. In our view, further studies increasing the number of patients will be required. Understanding the effects of dysregulation in the microbiota on the liver grafts and post-operative outcomes remains a challenge. It is well known that LT is conducted in emergency situations and it is very difficult to collect liver samples from the donor, especially in uncontrolled cardiac arrest conditions. In BD conditions, liver donors are often kept in intensive care units for periods of no longer than six hours after diagnosis of BD [104]. The time frame between declaration of brain death and organ procurement provides a small window for obtaining biological samples from the donor in order to analyze gut microbiota and derived products. Rapid and appropriate analysis of such aspects might improve the quality of liver grafts before implantation and consequently post-operative outcomes. This contention is based on previous preclinical studies that indicate that the levels of different mediators, including FGF15 and GLP-1 (both derived from the intestine), were altered in donors after BD or cardiocirculatory death (CD) induction. This resulted in hepatic damage and regenerative failure. On the other hand, the regulation of FGF15 and GLP-1 in donors improved the quality of liver grafts, and consequently post-operative outcomes, including the survival rate of recipients $[59,60,63]$.

Previous studies suggest that, among numerous injurious effects, intestinal microbiota regulate liver tumorigenesis or inflammatory reactions by altering the activity of proinflammatory microorganism-associated molecular patterns, bacterial metabolites, natural killer T (NKT) cell-mediated bile acid metabolism and prostaglandin-E2 (PGE2) mediated suppression of antitumor [105]. As a future perspective, randomized clinical studies and studies that include a sufficient number of marginal donor types will be required to elucidate the effect of surgery on the gut microbiota and how it affects the potential alterations in post-operative outcomes. Only armed with these understandings will we be able to solve the current clinical problem of LT, selecting the appropriate strategy to regulate the gut microbiota and minimize potential negative consequences and transferring experimental results into clinical practice.

A recent study aimed at investigating the fecal microbiome of liver recipients with abnormal/normal liver function indicated a decrease of fecal microbiome diversity in recipients with healthy livers and a higher abundance of opportunistic pathogens such as Klebsiella and Escherichia/Shigella in all liver recipients. The authors established a fecal microbiome index (with specific alterations in Staphylococcus and Prevotella) that could be 
used to distinguish between these types of LT [42]. This is of clinical interest, given the relevance of identifying and validating prognostic factors in LT.

\section{Relationship between Partial Hepatectomy and Gut Microbiota}

Since the last century, many investigations have been performed in order to understand the components related to liver regeneration (LR) [106]. Many pathways related to growth factors and cytokines have been investigated [107], such as FGF15, hepatocyte growth factor (HGF) or GLP-1 [108]. It is also known that some disease-related states like steatosis are related to a decrease in liver regeneration capability [109] and exacerbated hepatic I/R injury [110]. When a PH is performed, understanding of LR is required to improve post-operative outcomes and facilitate recovery of a fully functional liver. While mechanisms associated with liver regeneration have been widely researched, not many studies have considered the role of $I / R$, which is a procedure commonly used in clinical practice to prevent the bleeding during parenchyma resection [4,54,111]. Although the gut microbiota has attracted interest in recent years in different pathologies, few studies have evaluated the role of gut microbiota in post-operative outcomes in hepatic resections [13]. This possibility should not be overlooked, given the relationship between the intestine and the liver, the intestinal congestion occurring during total warm ischemia (which might modify gut microbiota) [112], and the results reporting that even in experimental models of partial hepatic I/R, increases in P-selectin, neutrophil and damage to the intestine were observed [9]. No evaluation of whether these alterations are associated with changes in the gut microbiota or its derived products has been carried out.

Among microbial-related components related to liver recovery after $\mathrm{PH}$, some of them, including endotoxins, BAs, SCFAs and probiotics have been evaluated by different authors [13]. In contrast to LT, the occurrence of the gut metabolite endotoxin is needed for liver regeneration. Indeed, the administration of gut-derived endotoxin induces the release of some hepatotrophic factors and the synthesis of DNA [113], critical for liver regeneration in PH conditions [14]. In hepatic resection, the amount of BA increases rapidly and may impair LR [114]. Also, in many diseases where dysbiosis has been described, such as NAFLD, NASH or cirrhosis, the reduced bacterial conversion of primary BAs to secondary BAs, affecting its regulation and thus probably affecting regeneration [12]. Whether alterations in the gut microbiota might affect the generation of secondary BAs by bacteria, thus affecting liver regeneration in hepatic resections remains to be elucidated. SCFAs are an important component of gut microbial fermentation and their regulation has been associated with many liver diseases [115]. Since they are related to providing energy to both gut and liver [116], their regulation is expected to be important in the first stages of liver regeneration.

BCAAs possess an aliphatic side-chain with a branch. BCAAs promote protein synthesis and glucose metabolism and are involved in fatty acid oxidation. BCAAs favor liver regeneration, nutrition status, and hepatic encephalopathy. BCAAs can also reduce oxidative stress and liver inflammation as it is also involved in lactate production [4]. Concerning liver surgery, a protective effect against I/ $R$ injury by amino acid supplementation has been demonstrated in experimental and several clinical studies [117]. For instance, in a study aimed to evaluate the impact of a personalized nutritional protocol with diet and oral BCAA supplementation to 1960 patients that underwent liver resections, authors concluded that intervention was a safe and effective approach that may impact on reducing the length of hospital stay [118]. In the same line, another study suggests that perioperative supplementation of a BCAAs-enriched nutrient-mixture is beneficial in reducing the morbidity associated with and in shortening the duration of hospitalization of patients with chronic liver disease who undergo liver resection for HCC [119]. The gut microbiota and amino acid alterations are involved in the progression of obesity and type 2 diabetes mellitus [120] and changes in gut microbiota and amino acid levels have been reported after surgery [121-123]. However, these results [121-123] are mainly reported on bariatric surgery, not in hepatic surgical conditions. Moreover, there are few studies 
indicating the beneficial effects of microbial-related compounds such as glutamine after its supplementation in $\mathrm{PH}[124,125]$. Intensive investigations will be required to elucidate whether the benefits induced by amino acid supplementation are due to a regulation over gut microbiota.

Some bacterial species, like Bifidobacterium or Lactobacillus, are related to liver injury and regeneration [108]. For example, the composition of Bifidobacterium is altered in patients with cirrhosis [126] and a lower quantity of Bifidobacterium has been seen in dysbiosis associated with cystic fibrosis [127]. A relationship has also been reported between some Bifidobacterium species and elevated interleukin-10 (IL-10) expression [128], associated with hepatoprotective effects [129]. Finally, some studies have aimed to evaluate the effects of the microbiota in liver regeneration and its mechanisms of action. For example, in mice treated with ampicillin, the decrease in ampicillin-sensitive commensal bacteria (Eubacteria, Lactobacillus and Clostridium) retarded hepatic regeneration after $67 \% \mathrm{PH}$ (Table 3). This increased interleukin-12 (IL-12) levels, activating hepatic NKT cells, which increased interferon- $\gamma$ and impeded liver regeneration [130]. In this case, the use of antibiotics might be useful to avoid potential infections, but their effect on the gut microbiota should be considered, since it might negatively affect liver regeneration.

Table 3. Preclinical studies in partial hepatectomy $(\mathrm{PH})$.

\begin{tabular}{|c|c|c|c|c|}
\hline Study & Surgery (IR/PH) & Population & Treatment & Effect/Alteration Post-Surgery \\
\hline $\begin{array}{l}\text { Xing et al. } \\
\text { (2005) } \\
\text { [112] }\end{array}$ & $\begin{array}{l}-\mathrm{I} / \mathrm{R}(20 \mathrm{~min} \\
\text { ischemia and } 22 \mathrm{~h} \\
\text { of reperfusion) }\end{array}$ & $\begin{array}{l}\text {-SD rats with normal liver. } \\
\text { Groups: } \\
\text {-Sham } \\
-\mathrm{I} / \mathrm{R} \\
n=6-10 / \text { group }\end{array}$ & No specified & $\begin{array}{l}\mathrm{I} / \mathrm{R} \rightarrow \uparrow \mathrm{ALT}, \mathrm{AST}, \mathrm{MDA}, \mathrm{LPS} \text { and } \\
\downarrow \mathrm{SOD} \text {. } \\
\mathrm{I} / \mathrm{R} \rightarrow \downarrow \text { Bifidobacteria, Lactobacilli } \\
\text { and } \uparrow \text { Enterobacterium, Enterococcus. } \\
\mathrm{I} / \mathrm{R} \rightarrow \uparrow \mathrm{BT} \text { to kidney, } \downarrow \text { intestinal } \\
\text { microvilli. }\end{array}$ \\
\hline $\begin{array}{l}\text { Nardone et } \\
\text { al. (2010) } \\
{[110]}\end{array}$ & $\begin{array}{l}-\mathrm{I} / \mathrm{R}(30 \mathrm{~min} \\
\text { ischemia and } 60 \\
\text { min reperfusion) }\end{array}$ & $\begin{array}{l}\text {-Male W rats with healthy } \\
\text { or steatotic liver. } \\
\text { Groups: } \\
\text {-Rats fed with Standard or } \\
\text { Steatogenic diet } \\
\text {-Rats fed with Standard or } \\
\text { steatogenic diet }+8 \text { week } \\
\text { probiotic supplementation } \\
n=7-10 / \text { group }\end{array}$ & $\begin{array}{c}\text { LP-F19 } \\
\text { supplementation }\end{array}$ & $\begin{array}{l}\mathrm{I} / \mathrm{R} \rightarrow \downarrow \text { Bacteroides, Bifidobacterium } \\
\text { and Lactobacillus and } \uparrow \text { Enterococcus, } \\
\text { and Enterobacteriaceae } \\
\mathrm{I} / \mathrm{R} \rightarrow \text { necrosis, leukocyte } \\
\text { infiltration, } \uparrow \text { MDA, TNF } \alpha, \mathrm{IL}-1 \beta, \\
\text { IL-6, ALT, AST and LPS, } \\
\text { (especially in steatotic livers). } \\
\text { LP-F19 } \rightarrow \downarrow \mathrm{I} / \mathrm{R} \text { injury in steatogen } \\
\text { diet, } \downarrow \downarrow \mathrm{I} / \mathrm{R} \text { in standard diet. }\end{array}$ \\
\hline $\begin{array}{l}\text { Wu et al. } \\
(2015) \\
{[130]}\end{array}$ & -PH (67\%) & $\begin{array}{l}\text {-Male C57Bl/ } 6 \text { mice with } \\
\text { healthy liver. } \\
\text { Groups: } \\
\text {-Mice undergoing PH } \\
\text {-Mice undergoing PH+Atb } \\
\text { treatment: Amp } \\
\text { Neo, } \\
\text { Met, } \\
\text { Vanco } \\
\text { (in combination or } \\
\text { separately). } \\
n=3-6 / \text { group }\end{array}$ & $\begin{array}{c}\text { (Atb-treatment): Amp, } \\
\text { Neo, Met, Vanco }\end{array}$ & $\begin{array}{l}\text { Atb in combination: no affect } \\
\text { hepatic damage (AST and ALT) } \\
\text { but } \downarrow \text { hepatic proliferation ( } \downarrow \text { PCNA, } \\
\text { BrdU-positive hepatocytes). } \\
\text { Vanco, Neo, Met alone } \rightarrow \text { no effect } \\
\text { on LR. } \\
\text { Amp } \rightarrow \downarrow \text { Amp-sensitive } \\
\text { commensal bacteria ( } \downarrow \text { many } \\
\text { gram-negative and gram-positive } \\
\text { bacteria } \rightarrow \uparrow \text { Kupffer cells and } \\
\uparrow I L-12 \rightarrow \uparrow \text { activation NKT } \\
\text { cells } \rightarrow \downarrow \text { LR }\end{array}$ \\
\hline
\end{tabular}


Table 3. Cont.

\begin{tabular}{|c|c|c|c|c|}
\hline Study & Surgery (IR/PH) & Population & Treatment & Effect/Alteration Post-Surgery \\
\hline $\begin{array}{l}\text { Liu et al. } \\
\text { (2016) } \\
{[13]}\end{array}$ & $-\mathrm{PH}(2 / 3)$ & $\begin{array}{l}\text {-Male C57BL/ } 6 \text { mice with } \\
\text { healthy liver } \\
\text { Groups: } \\
\text {-Control } \\
\text {-Mice undergoing PH } \\
\text { Time: } \\
0 \text { h-9 days. } \\
n=3,4 \text { /group. }\end{array}$ & No specified & $\begin{array}{l}\text {-PH: } \uparrow \text { Bacteroidetes (S24, } \\
\text { Rikenellaceae), } \downarrow \text { Firmicutes } \\
\text { (Clostridiales, Lachnospiraceae, and } \\
\text { Ruminococcaceae). } \\
\text {-Ruminococus, Bifidobacterium, } \\
\text { Lactobacillus and Clostridium } \\
\text { modulate bile acid conversion } \\
\downarrow \text { Firmicutes/Bacteroidetes ratio is } \\
\text { associated to lean microbiota; } \\
\uparrow \text { Ratio: obese mice. } \\
\text { High fat diet: } \uparrow \text { Rikenellaceae and } \\
\downarrow \text { Ruminicoccaceae. } \\
\text { Exercice: } \uparrow S 24-7 \rightarrow \uparrow \text { butyrate } \\
\uparrow \text { Ki67 following PH and liver size } \\
\text { was restored at } 7-9 \text { days. }\end{array}$ \\
\hline $\begin{array}{c}\text { Bao et al. } \\
(2020) \\
{[14]}\end{array}$ & $-\mathrm{PH}(2 / 3)$ & $\begin{array}{l}\text { Adult male SD rats } \\
(n=126) \text { with healthy liver. } \\
\text { Groups: } \\
\text {-Control } \\
\text {-Rats undergoing PH } \\
\text {-Rats undergoing PH+Atb } \\
\text { treatment } \\
\text {-Rats undergoing PH+Atb } \\
\text { +FMT treatment } \\
\text { Time: } 0-336 \mathrm{~h}\end{array}$ & $\begin{array}{l}\text {-Atb-treatment: } \\
\text { Amp, Vanco, Metro, } \\
\text { Neo (in combination) } \\
\text {-FMT treatment }\end{array}$ & $\begin{array}{l}\text { PH: -Inverse relation between } \\
\text { Bacteroidetes (Bacteroidaceae, } \\
\text { Prevotellaceae, Rikenellaceae, } \\
\text { Porphyromonadaceae) and Firmicutes } \\
\text { (Ruminococcaceae, Lachnospiraceae). } \\
\text { Bacteroidetes } \downarrow 12-24 \mathrm{~h}, \uparrow 30-48 \mathrm{~h} \\
\text { and } \downarrow 3-14 \text { days } \\
\text { Proteobacteria } \uparrow 48 \mathrm{~h} \\
\text { PH: } \uparrow \mathrm{Ki} 67, \text { BrdU, TNF } \alpha, \mathrm{IL}-6 \text { and } \\
\text { HGF. } \\
\text {-Atb treatment impaired LR ( } \downarrow \mathrm{Ki} 67 \\
\text { and BrdU) and FMT treatment } \\
\text { restored LR }\end{array}$ \\
\hline
\end{tabular}

$\uparrow:$ Increase; $\downarrow$ : Decrease; Amp: Ampicillin; ALT: Alanine transaminase; AST: Aspartate transaminase; Atb: Antibody; BrdU: Bromodeoxyuridine; BT: Bacterial translocation; FMT: Fecal microbial transplantation; HGF: Hepatocyte growth factor; I/R: Ischemia/reperfusion; Ki67; IL-1 $\beta$ : Interleukin-1 $\beta$; IL-6: Interleukin-6; IL-12: Interleukin-12; marker of proliferation Ki-67; LP-F19: Lactobacillus paracasei; LPS: Lipopolysaccharide; LR: Liver regeneration; MDA: Malondialdehyde; Met: Metronidazole; Neo: Neomycin sulfate; NKT: Natural killer T; PH: Partial hepatectomy; PCNA: Proliferating cell nuclear antigen; SD: Sprague Dawley; SOD: Superoxide dismutase; TNF $\alpha$ : Tumor necrosis factor $\alpha$; Vanco: Vancomycin; W: Wistar.

One study, by Xing et al. [112], describes alterations in the microbiota induced by I/R. Bifidobacteria and Lactobacilli decreased, while Enterobacterium and Enterococcus increased. This is also related to a decrease of microvilli, damage in the liver, an increase in plasmatic LPS and bacterial translocation to the kidney. Another article related to I/R indicates that supplementation with Lactobacillus paracasei F19 (LP-F19) restored the alterations in the gut microbiota and this was associated with protection against damage in both steatotic and non-steatotic livers [110].

In two articles $[13,14]$, authors mention dynamic changes in the microbiota and its metabolites during liver regeneration after $\mathrm{PH}$. The microbiota remained altered after the size of the liver was recovered. Also, although both performed a 2/3 $\mathrm{PH}$, their animal species were different (rats and mice), meaning the surgical procedures differed. Moreover, these differences might explain, at least partially, controversial results observed in both studies related to the dynamic profile of microbiota, metabolites and functional pathways described. Indeed, the studies by Liu et al. [13] indicated increases in Bacteroidetes and decreases in Firmicutes, whereas in the study reported by Bao et al. [14], the levels of Bacteroidetes were decreased and those of Firmicutes were increased.

Investigations aimed at evaluating the potential alterations in the microbiota in $\mathrm{PH}$ under I/R in livers with pathologies are of scientific and clinical interest since I/ $\mathrm{R}$ is commonly used in clinical practice to prevent bleeding during resection [6]. This is because this surgical procedure is often performed in subjects that present a disease associated with microbial and metabolite features different from a lean phenotype, such as NAFLD/NASH [131,132] and cirrhosis $[20,133]$. Studies focused on steatotic livers submitted for surgery might be of scientific and clinical interest since the gut microbiota influences lipogenesis and 
BAs [134]. Lipogenesis is affected by the absorption of SCFAs in the intestinal lumen by the microbiota [135]. In addition, the microbiota is able to deconjugate BAs and turn them into secondary BAs [136].

It is clear, from all the reported results of the effect of hepatic resections, that the surgical procedure by itself induces changes in the microbiota. However, the effect of these alterations on post-operative outcomes remains to be elucidated. In addition, inconclusive data might be obtained from the literature to date because the studies are limited: there are differing effects on bacterial profile reported for the same surgical procedures and, to our knowledge, no study has been focused on PH under I/R. Although it has been suggested that the products derived from the microbiota might play a key role in hepatic resections, further investigations are required using preclinical models that mimic clinical conditions as closely as possible including the ischemia times as commonly used in clinical practice (e.g., $60 \mathrm{~min}$ ) and both healthy and pathological livers. In such conditions, SCFAs, endotoxin levels, and secondary BAs should be evaluated. Therefore, depending on the preclinical results, the pharmacological modulation of products derived from the microbiota and consequent effects on liver injury and regeneration should be investigated. All of these factors need to be investigated to develop protection against hepatic damage and regenerative failure using strategies based on microbiota-derived products.

To our knowledge, no clinical studies aimed at evaluating the effects of hepatic resection on potential alterations in the gut microbiota have yet been reported.

\section{Gut Microbiota-Based Therapy}

Herein we show the different strategies reported to date to modulate alterations in the gut microbiota and its derived products.

\subsection{Pro/Prebiotics}

Current evidence has indicated advantages resulting from the use of probiotics to prevent infections after LT without major side effects [137]. Administration of Bifidobacterium and Lactobacillus ameliorated ischemia-reperfusion injury (IRI) in a mouse model by reducing plasma endotoxin levels and restoring the intestinal barrier function [138]. In addition, in a rat model of LT, such bacteria were increased after the induction of ischemic preconditioning and this reduced IRI [139], which suggest that probiotics effects could be similar to ischemic preconditioning benefits, a surgical technique with a protective role against IRI $[91,140]$. These effects were all explained by the production of SCFAs, immunomodulators which have the ability to reduce inflammation due to the regulation of macrophage activation [12,68].

A meta-analysis of four controlled studies $(n=246)$ demonstrated that LT patients treated with prebiotics and probiotics before or on the day of transplantation had a reduced infections rate after surgery ( $7 \%$ vs. $35 \%$ ) and shorter hospital and intensive care unit (ICU) stays as well as a reduction of the duration of antibiotic use [141]. An additional placebo-controlled clinical trial of probiotic treatment on 55 liver-transplant recipients showed significantly reduced 30- and 90-day infection rates, lower post-transplant bilirubin concentration and a more rapid decrease in transaminases [142].

It has been reported that prebiotics might decrease the rate of infections after orthotropic LT because they improve the function of the intestinal barrier, induce the secretion of mucous and immunoglobulin A, improve intestinal motility, decrease the synthesis of inflammatory cytokines and prevent the colonization of the gut by pathogenic bacteria. They can also enhance the production of SCFAs that in turn can be used as energy substrates for the intestinal cells and promote an effect similar to probiotics [143].

The effect of bowel decontamination using gentamycin versus a combination of three probiotics for one week before LT and continued for two weeks after LT on gut microbiota, liver histology, cytokines, and T cells were evaluated. The group treated with probiotics presented lower gut inflammation and a better preservation of gut epithelial barrier. Both antibiotic and probiotic groups showed decreased hepatic injury in the context of ACR. 
According to these data, the benefits of probiotics were attributed to the induction of intestinal Treg cells, increased levels of transforming growth factor $\beta$ (TGF- $\beta$ ) in plasma and a decrease in the CD4/CD8 ratio [86,137]. The mechanisms responsible for beneficial effects induced by the antibiotic treatment remain unclear.

On the other hand, according to three controlled trials in which the probiotics formulations contain Lactobacillus, prebiotics do not seem to have a clear impact over ACR. While there was a difference in ACR ( $20 \%$ in the probiotic group vs. $28 \%$ in the control group), this was not significant $[12,141,144-146]$. Nevertheless, studies that report data about the relationship between ACR and persistent dysbiosis concluded that this dysbiosis (that in part could be reverted thanks to prebiotics and probiotics) may be associated with one year mortality [12].

In $I / R$, the use of probiotics has also been investigated. For example, it has been reported that the supplementation of Lactobacillus paracasei F19 reduced the effects of I/R on the liver and on gut microbiota in rats fed with either a standard or steatogenic diet. Of interest, beneficial effects were more evident in the absence of steatosis [110].

\subsection{Antibiotics}

The administration of polymyxin B sulfate (for seven days) in rats undergoing LT reduced Enterobacteriaceae, while it increased Bifidobacterium, Lactobacillus, Bacteroides, and Eubacterium. This was associated with reduced endotoxemia and TNF- $\alpha$ production [147]. Similar effects were reported in one small retrospective study regarding another antibiotic: Rifaximin. It reports the benefits of this antibiotic regarding post-LT infections in patients with end-stage liver disease [148]. Two other retrospective studies conclude the same: that antibiotics such as rifaximin, neomycin, erythromycin and ampicillin-sulbactam prior to LT decreases infection, thus reducing liver injury, inflammation and early allograft dysfunction $[4,46,149]$. Only one randomized clinical trial assessed the effect of bowel decontamination on gut flora changes by investigating fecal cultures after LT. The study reported less gram-negative bacteria in the bowel decontamination group compared with controls, although no difference in infection rates after LT was noted [150]. Given the data, the role of gut decontamination alone remains unclear and it needs to be clearly elucidated [137]. The possibility of decontamination along with bacterial repopulation is discussed later.

Studies evaluating changes in gut microbial populations and diversity caused by hepatic I/ $R$ and their consequences for liver function and regeneration are limited. From 2014 to 2019, authors only examined the effect of therapeutic approaches on intestinal microbiota and hepatic injury and such strategies were mainly based on the use of antibiotics [4]. On the other hand, how the regulation in intestinal microbiota induced by the administration of antibiotics might positively affect hepatic functions remains to be clarified. In addition, none of these studies have been focused on evaluating the effects of the administration of antibiotics on alterations to the microbiota in steatotic or aged livers undergoing surgery.

The administration of antibiotics reduced hepatic injury in LT rats with ACR, but according to this study the gut barrier seems to be altered and disrupted affecting the microbiome diversity [86]. This is of clinical interest because antibiotics might be considered a useful strategy to regulate alterations in the gut microbiota if intestinal integrity is maintained.

As it can be seen above, some data remains unclear and contradictory, so further randomized clinical trials and LT models are required to elucidate the precise mechanisms of action of antibiotics, and how they could affect the liver function throughout the changing of the gut microbiome [4].

It should be noted that although the administration of antibiotics might reduce infections and to improve hepatic injury, other strategies should be evaluated because as shown in previous sections, hepatic injury, alterations in intestinal microbiota and BT, among other effects are present. Moreover, the side effects derived from the administration of antibiotics should be considered. One example is the destruction of the microvilli of the 
ileum epithelial cells observed in LT, as explained above. The use of antibiotics is associated with multidrug-resistant bacteria. A recent study indicates that multidrug-resistant bacteria colonization could be a major marker of persistent dysbiosis in liver transplant patients, causing this microbiome imbalance to have negative effects on liver function [151].

\subsection{Diet and Components that Modulate the Gut Microbiota}

Some papers have reported that a short-term starvation could ameliorate liver function by reducing necrosis and apoptosis associated with I/R injury [152,153] or PH [154], thus resulting in a better post-operative outcome. However, other papers indicate that starvation could negatively affect I/R associated to either LT or PH [4,155]. In this line, preclinical results in PH indicate depletion of butyrate and alterations in the composition and function of microbiome under overnight fasting conditions that negatively affect the post-operative outcomes [156]. The different effects on starvation depend on the type of the liver submitted to surgery. Thus, the starvation in fatty livers submitted to liver surgery is associated with exacerbated I/R damage [157]. It should also be taken into account several limitations including the time of starvation required in the clinical practice, especially in the case of LT from $\mathrm{BD}$ or $\mathrm{CD}$ donors by the emergency situation and the derived-logistic problems.

The use of time-restricted feeding (TRF) prior to surgery reduced the damage, oxidative stress and inflammatory biomarkers associated with I/R injury, probably due to intestinal increases in the Firmicutes phylum, Clostridia and Bacilli classes, Clostridiales and Lactobacillales orders, and Lachnospiraceae and Ruminococcaceae families, bacteria that are clearly associated with a healthy gut phenotype $[4,158,159]$. However, different results have been reported regarding the diet restriction since, under these conditions, endotoxemia, increased TNF- $\alpha$ and BT, and less Bifidobacteria and Lactobacillus in the ileum were observed after LT [160].

On the other hand, it has been reported that the nutritional status previous to the surgery, the damage resulting from LT or $\mathrm{PH}$, along with the type of liver submitted to liver surgery, can increase the risk of post-operative failure [4,76]. Patients with endstage liver diseases who require LT tend to present malnutrition, as it is also related to microbiota negative features such as dysbiosis and BT [76]. Thus, many groups have reported different diet requirements and compounds to avoid the problems associated with the malnutrition of patients requiring a liver surgery. Enteral immunonutrition and other dietary regimens such as all-trans retinoic acid (RA) seem to have beneficial effects on liver surgeries, promoting liver regeneration. The administration of RA forty-eight hours before $\mathrm{PH}$ was associated with a reduced ratio of Firmicutes to Bacteroidetes, described as a healthy phenotype [109]. Nevertheless, no study clearly identifies a relationship between RA, gut microbiota and liver regeneration, which could lead to the development of new therapeutic strategies. Enteral immunonutrition enriched with nucleotides, arginine, omega-3 fatty acids and hydrolyzed whey peptide (HWP) (started within the first $24 \mathrm{~h}$ after surgery) seems to diminish infection risk in liver transplanted recipients, according to one retrospective study [161].

The treatment with glutamine immediately before surgery improves liver regeneration in PH [124] as well as the administration of glutamine during at least three days before LT improves the stability of the intestinal barrier and endotoxemia in LT [162].

In $\mathrm{PH}$ and LT, the treatment with probiotics (i.e., Enterococcus faecalis, Clostridium butyricum or Bacillus mesentericus) or synbiotics (the combined administration of prebiotics and probiotics) pre-and post-surgery improves the gut microbiota and reduces the negative effects associated to dysbiosis such as an increase in intestinal permeability, immune alterations and infections, [146,163-165].

These are other studies based on the following treatments in liver surgery: lipid emulsion or carbohydrate supplementation just after PH maintain ATP levels, reduces liver damage and increases liver regeneration [166]; the treatment of omega-3 fatty acids three days before liver surgery and one after surgery protects liver against inflammation and damage associated with PH [167]; the treatment with BCAAs prior to surgery im- 
proves liver regeneration and decreases liver damage [168,169]; finally, the treatment with dexpanthenol (pro-vitamin B5) immediately before surgery decreases I/R injury [170]. Further investigations will be required to elucidate whether the benefits induced by such compounds in $\mathrm{PH}$ and $\mathrm{LT}$ are mediated by a regulation in gut microbiota. This possibility should not be discarded because of the numerous papers reported in the literature that describe changes in gut microbiota induced by lipids [171], carbohydrates [172], and amino acids [173] in different liver diseases.

In our view, whether (a) changes in diet regulate dysbiosis and (b) dysbiosis negatively affect the graft viability and the post-operative outcomes in the surgery of hepatic resections and LT, changes in the diet should be applied before surgery to diminish the detrimental effects of $\mathrm{PH}, \mathrm{BD}$ or $\mathrm{CD}$ before livers grafts are retrieved from donors. All of this should be investigated in order to promote better preservation of the organ and to improve the outcome after liver surgery. By the emergency situation of LT, such strategies might be more feasible in the liver surgery of hepatic resections.

\section{Conclusions}

For many years, several therapeutic strategies to reduce damage and regenerative failure in both healthy and pathological livers in resections or transplantation have been attempted, mainly focused on the pathological mechanisms occurring in the liver. However, none have been successfully transferred to clinical practice. In our view, exploration of alternative strategies evaluating not only the liver but also other organs closely related to liver function is required. In particular, the gut, which exhibits a close anatomical and functional bidirectional interaction with the liver, mainly through the portal circulation.

The involvement of alterations in gut metabolites and microbiota in the pathogenesis and progression of NAFLD is well known. However, the role of dysbiosis in the gut microbiota in either LT or PH is yet to be elucidated and current results are controversial. Some clinical studies show no significant microbiota differences in the early post-transplantation stage nor in recipients with acute-cellular rejection or post-LT bloodstream infections, whereas there are many other clinical and preclinical studies with contrary results. Although the gut barrier can be compromised during LT affecting gut microbiota, it is not clear whether pre-transplant gut microbiota in patients with cirrhosis or end-stage liver disease may have a more powerful influence on dysbiosis than LT itself. In our view, comparison of the gut microbiota status in patients (a) immediately before implantation of the liver graft and (b) after LT, would reveal whether the surgery itself plays a key role in the alterations in the gut microbiota observed after LT. To date, preclinical studies focusing on the gut microbiota in LT have not included liver grafts with pathological conditions such as steatotic or aged liver grafts, those with viral infections or grafts from $\mathrm{BD}$ or DCD. Future studies that include marginal donors will be required to elucidate the effect of surgery on the gut microbiota when liver grafts exhibit comorbidities that are commonly found in clinical practice. This is extremely important because it is known that the signaling mechanisms in LT can differ greatly between optimal and marginal grafts. In addition, livers with pathological conditions (such as steatosis) exhibit differences in intestinal microbiota diversity in comparison with healthy livers.

Regarding PH conditions, vascular occlusion is a procedure commonly used in clinical practice to prevent bleeding during parenchyma resection. However, very few studies evaluating the role of the gut microbiota in post-operative outcomes in hepatic resections have included I/R in their experimental models. Dynamic changes in microbiota and its metabolites during liver regeneration after $\mathrm{PH}$ have been revealed from such investigations. Interestingly, in experimental conditions of $\mathrm{I} / \mathrm{R}$ without $\mathrm{PH}$, microbiota dysbiosis was also demonstrated after surgical procedures. Taken together, these results seem to indicate that the surgical procedure itself induces changes in the microbiota; however, they cannot be considered conclusive data because the studies are limited and of limited clinical relevance since the vascular occlusion occurring in clinical hepatic resections has not been considered in any such preclinical studies. Thus, future studies that include resection and ischemia 
to approximate what happens in clinical practice are required. Investigations aimed at evaluating the potential alterations in the microbiota in $\mathrm{PH}$ under I/ $\mathrm{R}$ in pathological livers are also of scientific and clinical interest, because this surgical procedure is often performed in subjects with liver disease (such as NAFLD/NASH or cirrhosis), which is associated with different microbial and metabolite features than those described in healthy livers.

Dysbiosis in the gut microbiota affects signaling pathways such FXR and TGR5, inducing bacterial translocation, among other effects, and contributing to liver disease progression. In addition, dysregulation of intestinal microbiota causes alterations in SCFA generation, increasing immune system activity, which might result in greater risk of graft rejection. As SCFAs are also related to providing energy to the gut and liver, their regulation seems to be important in the early stages of liver regeneration in hepatic resection. In contrast to its occurrence in LT, endotoxin is one of the gut metabolites needed for liver regeneration, which is critical in $\mathrm{PH}$ conditions. The role of such metabolites in LT or resection with both healthy and pathological livers remains to be explored. This is especially crucial for amino acids due to the limited studies reported in the literature. Pharmacological modulation of the products derived from the microbiota and their effects on liver injury and regeneration should be investigated to design effective strategies to regulate the gut microbiota and improve post-operative outcomes in liver surgery.

The interrelation between the gut microbiota and liver surgery presents a huge area of opportunity for future therapeutic perspectives. Therapies based on gut microbiota regulation, such as treatments with probiotics, prebiotics, antibiotics, preoperative fasting or pre and post-operative diet have promising results in hepatic I/R injury, gut microbiota and liver regeneration. Further studies, mainly focused on the effects of preoperative fasting or pre and post-operative diet on gut microbiota in liver surgery are required. It should also be considered that the types of liver, surgical procedures as well as the nutritional status of the subjects prior to surgery differentially affect the microbiome. Thus, specific protective strategies to regulate the microbiome alterations and consequently the post-operative outcomes in PH and LT might be required.

The administration of antibiotics should be undertaken with caution, since in rats with acute rejection after LT, it reduced hepatic damage but led to injury to intestinal integrity, thus inducing alterations in the microbiota. Further research is necessary to elucidate the molecular signaling pathways through which antibiotics may exert their actions, whether the protection against hepatic damage induced by antibiotics is exerted through changes in the gut microbiome, and to determine the optimal dose and duration of treatments. Moreover, the side effects of antibiotics, such as the presence of multidrugresistant bacteria, should be taken into account. Understanding the relationship between the gut microbiota and liver surgery could also generate new biomarkers of liver status in resection or LT. Interesting results from several studies suggest that multidrug-resistant bacteria colonization could be a major marker of persistent dysbiosis and liver function in LT recipients and fecal microbiome diversity might be used to distinguish either abnormal or normal liver function after LT.

Preclinical studies exploring the interrelation of the gut microbiota and liver surgery are notorious for their failure to reflect what actually occurs in clinical practice. Experimental studies have been carried out in the absence of BD or DCD, which means in surgical conditions very different to those occurring in clinical practice. BD and CD induce important hemodynamic changes, hypoperfusion in the mesenteric microcirculation and warm hepatic ischemia, which might result in important alterations in the mediators generated in the intestine, intestinal damage, dysregulation in BAs and inflammation. All of this might induce changes in the diversity of the microbiota as well as in its metabolic products and exert injurious effects on liver grafts submitted for transplantation. In addition, experimental studies of the gut microbiota and LT have not included pathological liver grafts, and in some such studies, liver grafts were not subjected to cold ischemia, whereas it is widely known that $6-8 \mathrm{~h}$ of cold ischemia is commonly used in clinical practice. In addition, the success or dysfunction of liver grafts may be affected by other factors including donor 
age, presence of steatosis, cold ischemia times and type of donor (BD or CD). These conditions should be considered in future research to comprehend how they influence the gut microbiota. Regarding liver resection, there is also a lack of research using experimental models that best mimic clinical conditions, for example, the ischemic times commonly used or including both healthy and pathological livers. Of relevance, post-operative outcomes in liver resection are influenced by the presence of pathologies in liver, such as steatosis or cirrhosis, because they increase hepatic damage and impair regeneration. Because the effectiveness of a therapeutic strategy aimed at regulating potential alterations in the gut microbiota and its derived products could differ depending on surgical conditions, type of liver and other factors, the use of experimental models that reproduce as closely as possible real clinical conditions is especially important to afford an effective translation of laboratory results to patients.

So far, research on the interrelation between the gut microbiota and liver surgery is in its infancy and there is still much to do. The knowledge that has been generated to date is very limited and it still does not allow us to clearly distinguish the alterations that the intestinal microbiota or its metabolic products induce on postsurgical outcomes in LT or resection; nor whether it is the surgery itself that causes such alterations that could in turn affect post-operative results. Much less is known about the molecular mechanisms involved in these events, and therefore, therapeutic targets that can be used in the design of future treatments in liver surgery, based on the regulation of the gut microbiota or its metabolic products have yet to be defined. The discoveries generated from the first investigations into the complex interrelationship between the microbiota and liver surgery clearly show the need for the design of appropriate preclinical models of surgery that closely approximate clinical practice. This is crucial for establishing therapies to combat hepatic damage and regenerative failure based on microbiota regulation, which can be successfully translated into clinical practice.

Author Contributions: Conceptualization, M.M.-C., C.R.-A., A.I.Á.-M., J.G.-S., A.C.-R. and C.P.; writing-Original draft preparation, M.M.-C., C.R.-A., A.I.Á.-M., A.C.-R. and C.P.; writing-Review and editing, M.M.-C., C.R.-A., A.I.Á.-M., J.G.-S., A.C.-R. and C.P.; and funding acquisition, C.P. All authors have read and agree to the published version of the manuscript.

Funding: This research was supported by the "Ministerio de Ciencia, Innovación y Universidades (MCIU)" (RTI2018-095114-B-I00) Madrid, Spain, by the European Union (Fondos Feder, "Una manera de hacer Europa"), by "CERCA Program/Generalitat de Catalunya", and by the "Secretaria d'Universitats i Recerca" (2017SGR-551) Barcelona, Spain and by the COST action Programs CA17103 (DARTER) and CA17126 (TUMIEE).

Institutional Review Board Statement: Not applicable.

Informed Consent Statement: Not applicable.

Data Availability Statement: Not applicable.

Acknowledgments: We thank Toffa (Language Advisory Service, University of Barcelona, Barcelona, Spain) for revising the English text.

Conflicts of Interest: The authors declare no conflict of interest.

$\begin{array}{ll}\text { Abbreviations } & \\ \text { AAs } & \text { Amino acids } \\ \text { ACR } & \text { Acute-cell rejection } \\ \text { ALD } & \text { Alcoholic liver disease } \\ \text { ALT } & \text { Alanine transaminase } \\ \text { Amp } & \text { Ampicillin } \\ \text { AR } & \text { Acute rejection } \\ \text { AST } & \text { Aspartate transaminase } \\ \text { Atb } & \text { Antibody } \\ \text { BA } & \text { Bile acid }\end{array}$




\begin{tabular}{|c|c|}
\hline BCAA & Branched-chain amino acid \\
\hline $\mathrm{BD}$ & Brain-dead \\
\hline $\mathrm{BN}$ & Brown Norway \\
\hline BrdU & Bromodeoxyuridine \\
\hline BT & Bacterial translocation \\
\hline $\mathrm{CD}$ & Cardiac death \\
\hline CNIs & Calcineurin inhibitors \\
\hline CVD & Cardiovascular disease \\
\hline CYP7A1 & Cytochrome P450 7A1 \\
\hline DCA & Deoxycholic acid \\
\hline DCD & Donation after circulatory death \\
\hline ESLD & End-stage liver disease \\
\hline FGF15 & Fibroblast growth factor 15 \\
\hline FGFR4-KLB & Fibroblast growth factor receptor- 4 and its co-receptor klotho-beta \\
\hline FMT & Fecal microbial transplantation \\
\hline FXR & Farnesoid X receptor \\
\hline GC & Glucocorticoids \\
\hline GLP-1 & Glucagon-like peptide 1 \\
\hline GM & Gut microbiota \\
\hline Gln & Glutamine \\
\hline $\mathrm{HCC}$ & Hepatocellular carcinoma \\
\hline HGF & Hepatocyte growth factor \\
\hline HWP & Hydrolyzed whey peptide \\
\hline $\mathrm{I} / \mathrm{R}$ & Ischemia/reperfusion \\
\hline ICAM & Intercellular adhesion molecule \\
\hline ICU & Intensive care unit \\
\hline IL & Interleukin \\
\hline IL-1 $\beta$ & Interleukin-1 $\beta$ \\
\hline IL-6 & Interleukin-6 \\
\hline IL-10 & Interleukin-10 \\
\hline IL-12 & Interleukin-12 \\
\hline IRI & Ischemia/reperfusion injury \\
\hline IS & Immunosuppression \\
\hline Ki67 & Marker of proliferation Ki-67 \\
\hline $\mathrm{L}$ & Lewis \\
\hline LCA & Lithocholic acid \\
\hline LD & Linear dichroism \\
\hline LN & Liver transplantation in normal receptors \\
\hline LP-F19 & Lactobacillus paracasei F19 \\
\hline LPS & Lipopolysaccharides \\
\hline LR & Liver regeneration \\
\hline LT & Liver transplantation \\
\hline LTA & Abnormal liver function \\
\hline LTC & Liver transplantation in cirrhotic receptors \\
\hline LTN & Liver transplantation in normal receptors \\
\hline LTN & Normal liver function \\
\hline LTRs & Liver-transplant recipients \\
\hline MDA & Malondialdehyde \\
\hline Met & Metronidazole \\
\hline MP & Methylprednisolone \\
\hline MPA & Mycophenolate \\
\hline Muc2 & Mucin 2 \\
\hline Muc3 & Mucin 3 \\
\hline NAFLD & Non-alcoholic fatty liver disease \\
\hline NASH & Non-alcoholic steatohepatitis \\
\hline Neo & Neomycin sulfate \\
\hline NFKB & Nuclear factor kappa-light-chain-enhancer of activated B cells \\
\hline NKT cell & Natural killer-T cell \\
\hline
\end{tabular}




$\begin{array}{ll}\text { NLRs } & \text { Nod-like receptors } \\ \text { NR } & \text { Non-rejection group } \\ \text { OLT } & \text { Orthotropic liver transplant } \\ \text { PCNA } & \text { Proliferating cell nuclear antigen } \\ \text { PGE2 } & \text { Prostaglandin E2 } \\ \text { PH } & \text { Partial hepatectomy } \\ \text { RA } & \text { All-trans retinoic acid } \\ \text { ROS } & \text { Reactive oxygen species } \\ \text { R TGR5 } & \text { Receptor of Takeda G protein-coupled receptor 5 } \\ \text { SCFAs } & \text { Short-chain fatty acids } \\ \text { SD } & \text { Sprague Dawley } \\ \text { sIgA } & \text { Secretory IgA } \\ \text { SOD } & \text { Superoxide dismutase } \\ \text { TGF- } \beta & \text { Transforming growth factor } \beta \\ \text { TGR5 } & \text { Takeda G protein-coupled receptor } 5 \\ \text { TJ } & \text { Tight junction } \\ \text { TLR } & \text { Toll-like receptor } \\ \text { TLR4 } & \text { Toll-like receptor } 4 \\ \text { TMP-SMX } & \text { Trimethoprim-sulfamethoxazole } \\ \text { TNF } & \text { Tumor necrosis factor } \\ \text { TNF } \alpha & \text { Tumor necrosis factor } \alpha \\ \text { Treg } & \text { Regulatory T cells } \\ \text { TRF } & \text { Time-restricted feeding } \\ \text { Vanco } & \text { Vancomycin } \\ \text { W } & \text { Wistar }\end{array}$

\section{References}

1. Álvarez-Mercado, A.I.; Gulfo, J.; Romero Gómez, M.; Jiménez-Castro, M.B.; Gracia-Sancho, J.; Peralta, C. Use of Steatotic Grafts in Liver Transplantation: Current Status. Liver Transplant. 2019, 25, 771-786. [CrossRef] [PubMed]

2. Cillo, U.; Bechstein, W.O.; Berlakovich, G.; Dutkowski, P.; Lehner, F.; Nadalin, S.; Saliba, F.; Schlitt, H.J.; Pratschke, J. Identifying risk profiles in liver transplant candidates and implications for induction immunosuppression. Transplant. Rev. 2018, 32, 142-150. [CrossRef] [PubMed]

3. Núñez, K.; Thevenot, P.; Alfadhli, A.; Cohen, A. Complement activation in liver transplantation: Role of donor macrosteatosis and implications in delayed graft function. Int. J. Mol. Sci. 2018, 19. [CrossRef] [PubMed]

4. Cornide-Petronio, M.E.; Álvarez-Mercado, A.I.; Jiménez-Castro, M.B.; Peralta, C. Current Knowledge about the Effect of Nutritional Status, Supplemented Nutrition Diet, and Gut Microbiota on Hepatic Ischemia-Reperfusion and Regeneration in Liver Surgery. Nutrients 2020, 12. [CrossRef] [PubMed]

5. Peralta, C.; Jiménez-Castro, M.B.; Gracia-Sancho, J. Hepatic ischemia and reperfusion injury: Effects on the liver sinusoidal milieu. J. Hepatol. 2013, 59, 1094-1106. [CrossRef] [PubMed]

6. Heydari, M.; Cornide-Petronio, M.E.; Jiménez-Castro, M.B.; Peralta, C. Data on adiponectin from 2010 to 2020: Therapeutic target and prognostic factor for liver diseases? Int. J. Mol. Sci. 2020, 21, 1-24. [CrossRef]

7. Miyauchi, T.; Uchida, Y.; Kadono, K.; Hirao, H.; Kawasoe, J.; Watanabe, T.; Ueda, S.; Jobara, K.; Kaido, T.; Okajima, H.; et al. Preventive Effect of Antioxidative Nutrient-Rich Enteral Diet Against Liver Ischemia and Reperfusion Injury. J. Parenter. Enter. Nutr. 2019, 43, 133-144. [CrossRef]

8. Monson, K.M.; Dowlatshahi, S.; Crockett, E.T. CXC-chemokine regulation and neutrophil trafficking in hepatic ischemiareperfusion injury in P-selectin/ICAM-1 deficient mice. J. Inflamm. 2007, 4. [CrossRef]

9. Peralta, C.; Fernández, L.; Panés, J.; Prats, N.; Sans, M.; Piqué, J.M.; Gelpí, E.; Roselló-Catafau, J. Preconditioning protects against systemic disorders associated with hepatic ischemia-reperfusion through blockade of tumor necrosis factor-induced P-selectin up-regulation in the rat. Hepatology 2001, 33, 100-113. [CrossRef]

10. Yang, H.J.; Tang, L.M.; Zhou, X.J.; Qian, J.; Zhu, J.; Lu, L.; Wang, X.H. Ankaflavin ameliorates steatotic liver ischemia-reperfusion injury in mice. Hepatobiliary Pancreat. Dis. Int. 2015, 14, 619-625. [CrossRef]

11. Albillos, A.; de Gottardi, A.; Rescigno, M. The gut-liver axis in liver disease: Pathophysiological basis for therapy. J. Hepatol. 2020, 72, 558-577. [CrossRef] [PubMed]

12. Kriss, M.; Verna, E.C.; Rosen, H.R.; Lozupone, C.A. Functional Microbiomics in Liver Transplantation: Identifying Novel Targets for Improving Allograft Outcomes. Transplantation 2019, 103, 668-678. [CrossRef] [PubMed]

13. Liu, H.X.; Rocha, C.S.; Dandekar, S.; Yvonne Wan, Y.J. Functional analysis of the relationship between intestinal microbiota and the expression of hepatic genes and pathways during the course of liver regeneration. J. Hepatol. 2016, 64, 641-650. [CrossRef] [PubMed] 
14. Bao, Q.; Yu, L.; Chen, D.; Li, L. Variation in the gut microbial community is associated with the progression of liver regeneration. Hepatol. Res. 2020, 50, 121-136. [CrossRef]

15. Bajaj, J.S.; Kakiyama, G.; Cox, I.J.; Nittono, H.; Takei, H.; White, M.; Fagan, A.; Gavis, E.A.; Heuman, D.M.; Gilles, H.C.; et al. Alterations in gut microbial function following liver transplant. Liver Transplant. 2018, 24, 752-761. [CrossRef]

16. Meroni, M.; Longo, M.; Dongiovanni, P. Alcohol or Gut Microbiota: Who Is the Guilty? Int. J. Mol. Sci. 2019, 20, 1-22. [CrossRef]

17. Milosevic, I.; Vujovic, A.; Barac, A.; Djelic, M.; Korac, M.; Spurnic, A.R.; Gmizic, I.; Stevanovic, O.; Djordjevic, V.; Lekic, N.; et al. Gut-liver axis, gut microbiota, and its modulation in the management of liver diseases: A review of the literature. Int. J. Mol. Sci. 2019, 20, 1-16. [CrossRef]

18. Wang, Z.; Klipfell, E.; Bennett, B.J.; Koeth, R.; Levison, B.S.; Dugar, B.; Feldstein, A.E.; Britt, E.B.; Fu, X.; Chung, Y.M.; et al. Gut flora metabolism of phosphatidylcholine promotes cardiovascular disease. Nature 2011, 472, 57-65. [CrossRef]

19. Hsu, C.N.; Lu, P.C.; Lo, M.H.; Lin, I.C.; Chang-Chien, G.P.; Lin, S.; Tain, Y.L. Gut microbiota-dependent trimethylamine N-oxide pathway associated with cardiovascular risk in children with early-stage chronic kidney disease. Int. J. Mol. Sci. 2018, 19, 1-11. [CrossRef]

20. Nishikawa, H.; Enomoto, H.; Nishiguchi, S.; Iijima, H. Liver cirrhosis and sarcopenia from the viewpoint of dysbiosis. Int. J. Mol. Sci. 2020, 21, 1-24. [CrossRef]

21. Dumas, M.E.; Barton, R.H.; Toye, A.; Cloarec, O.; Blancher, C.; Rothwell, A.; Fearnside, J.; Tatoud, R.; Blanc, V.; Lindon, J.C.; et al. Metabolic profiling reveals a contribution of gut microbiota to fatty liver phenotype in insulin-resistant mice. Proc. Natl. Acad. Sci. USA 2006, 103, 12511-12516. [CrossRef] [PubMed]

22. Gao, Y.; Yang, L.; Chin, Y.; Liu, F.; Li, R.W.; Yuan, S.; Xue, C.; Xu, J.; Tang, Q. Astaxanthin n-octanoic acid diester ameliorates insulin resistance and modulates gut microbiota in high-fat and high-sucrose diet-fed mice. Int. J. Mol. Sci. 2020, 21. [CrossRef] [PubMed]

23. Sun, M.; Wu, W.; Liu, Z.; Cong, Y. Microbiota metabolite short chain fatty acids, GPCR, and inflammatory bowel diseases. J. Gastroenterol. 2017, 52, 1-8. [CrossRef] [PubMed]

24. Konturek, P.; Harsch, I.; Konturek, K.; Schink, M.; Konturek, T.; Neurath, M.; Zopf, Y. Gut-Liver Axis: How Do Gut Bacteria Influence the Liver? Med. Sci. 2018, 6, 79. [CrossRef]

25. Poeta, M.; Pierri, L.; Vajro, P. Gut-Liver Axis Derangement in Non-Alcoholic Fatty Liver Disease. Children 2017, 4, 66. [CrossRef]

26. Adolph, T.E.; Grander, C.; Moschen, A.R.; Tilg, H. Liver-Microbiome Axis in Health and Disease. Trends Immunol. 2018, 39, 712-723. [CrossRef]

27. Brun, P.; Castagliuolo, I.; Di Leo, V.; Buda, A.; Pinzani, M.; Palù, G.; Martines, D. Increased intestinal permeability in obese mice: New evidence in the pathogenesis of nonalcoholic steatohepatitis. Am. J. Physiol. Gastrointest. Liver Physiol. 2007, 292, 518-525. [CrossRef]

28. Harte, A.L.; Da Silva, N.F.; Creely, S.J.; McGee, K.C.; Billyard, T.; Youssef-Elabd, E.M.; Tripathi, G.; Ashour, E.; Abdalla, M.S.; Sharada, H.M.; et al. Elevated endotoxin levels in non-alcoholic fatty liver disease. J. Inflamm. 2010, 7, 1-10. [CrossRef]

29. Wang, C.; Zhu, C.; Shao, L.; Ye, J.; Shen, Y.; Ren, Y. Role of bile acids in dysbiosis and treatment of nonalcoholic fatty liver disease. Mediators Inflamm. 2019, 2019. [CrossRef]

30. Benten, D.; Wiest, R. Gut microbiome and intestinal barrier failure-The "achilles heel" in hepatology? J. Hepatol. 2012, 56, 1221-1223. [CrossRef]

31. Chen, Y.; Ji, F.; Guo, J.; Shi, D.; Fang, D.; Li, L. Dysbiosis of small intestinal microbiota in liver cirrhosis and its association with etiology. Sci. Rep. 2016, 6, 1-9. [CrossRef] [PubMed]

32. De Minicis, S.; Rychlicki, C.; Agostinelli, L.; Saccomanno, S.; Candelaresi, C.; Trozzi, L.; Mingarelli, E.; Facinelli, B.; Magi, G.; Palmieri, C.; et al. Dysbiosis contributes to fibrogenesis in the course of chronic liver injury in mice. Hepatology 2014, 59, 1738-1749. [CrossRef] [PubMed]

33. Douhara, A.; Moriya, K.; Yoshiji, H.; Noguchi, R.; Namisaki, T.; Kitade, M.; Kaji, K.; Aihara, Y.; Nishimura, N.; Takeda, K.; et al. Reduction of endotoxin attenuates liver fibrosis through suppression of hepatic stellate cell activation and remission of intestinal permeability in a rat non-alcoholic steatohepatitis model. Mol. Med. Rep. 2015, 11, 1693-1700. [CrossRef] [PubMed]

34. Maccioni, L.; Gao, B.; Leclercq, S.; Pirlot, B.; Horsmans, Y.; De Timary, P.; Leclercq, I.; Fouts, D.; Schnabl, B.; Stärkel, P. Intestinal permeability, microbial translocation, changes in duodenal and fecal microbiota, and their associations with alcoholic liver disease progression in humans. Gut Microbes 2020, 12. [CrossRef]

35. Malaguarnera, G.; Giordano, M.; Nunnari, G.; Bertino, G.; Malaguarnera, M. Gut microbiota in alcoholic liver disease: Pathogenetic role and therapeutic perspectives. World J. Gastroenterol. 2014, 20, 16639-16648. [CrossRef]

36. Seo, B.; Jeon, K.; Moon, S.; Lee, K.; Kim, W.K.; Jeong, H.; Cha, K.H.; Lim, M.Y.; Kang, W.; Kweon, M.N.; et al. Roseburia spp. Abundance Associates with Alcohol Consumption in Humans and Its Administration Ameliorates Alcoholic Fatty Liver in Mice. Cell Host Microbe 2020, 27, 25-40.e6. [CrossRef]

37. Chen, L.; van den Munckhof, I.C.L.; Schraa, K.; ter Horst, R.; Koehorst, M.; van Faassen, M.; van der Ley, C.; Doestzada, M.; Zhernakova, D.V.; Kurilshikov, A.; et al. Genetic and Microbial Associations to Plasma and Fecal Bile Acids in Obesity Relate to Plasma Lipids and Liver Fat Content. Cell Rep. 2020, 33, 108212. [CrossRef]

38. Udayappan, S.; Manneras-Holm, L.; Chaplin-Scott, A.; Belzer, C.; Herrema, H.; Dallinga-Thie, G.M.; Duncan, S.H.; Stroes, E.S.G.; Groen, A.K.; Flint, H.J.; et al. Oral treatment with Eubacterium hallii improves insulin sensitivity in db/db mice. NPJ Biofilms Microb. 2016, 2. [CrossRef] 
39. Tonin, F.; Arends, I.W.C.E. Latest development in the synthesis of ursodeoxycholic acid (UDCA): A critical review. Beilstein J. Org. Chem. 2018, 14, 470-483. [CrossRef]

40. Kurilshikov, A.; Van Den Munckhof, I.C.L.; Chen, L.; Bonder, M.J.; Schraa, K.; Rutten, J.H.W.; Riksen, N.P.; De Graaf, J.; Oosting, M.; Sanna, S.; et al. Gut Microbial Associations to Plasma Metabolites Linked to Cardiovascular Phenotypes and Risk: A Cross-Sectional Study. Circ. Res. 2019, 124, 1808-1820. [CrossRef]

41. Munukka, E.; Rintala, A.; Toivonen, R.; Nylund, M.; Yang, B.; Takanen, A.; Hänninen, A.; Vuopio, J.; Huovinen, P.; Jalkanen, S.; et al. Faecalibacterium prausnitzii treatment improves hepatic health and reduces adipose tissue inflammation in high-fat fed mice. ISME J. 2017, 11, 1667-1679. [CrossRef] [PubMed]

42. Lu, H.F.; Ren, Z.G.; Li, A.; Zhang, H.; Xu, S.Y.; Jiang, J.W.; Zhou, L.; Ling, Q.; Wang, B.H.; Cui, G.Y.; et al. Fecal microbiome data distinguish liver recipients with normal and abnormal liver function from healthy controls. Front. Microbiol. 2019, 10, 1-13. [CrossRef] [PubMed]

43. Qin, N.; Yang, F.; Li, A.; Prifti, E.; Chen, Y.; Shao, L.; Guo, J.; Le Chatelier, E.; Yao, J.; Wu, L.; et al. Alterations of the human gut microbiome in liver cirrhosis. Nature 2014, 513, 59-64. [CrossRef] [PubMed]

44. Li, Q.; Ma, L.; Shen, S.; Guo, Y.; Cao, Q.; Cai, X.; Feng, J.; Yan, Y.; Hu, T.; Luo, S.; et al. Intestinal dysbacteriosis-induced IL-25 promotes development of HCC via alternative activation of macrophages in tumor microenvironment. J. Exp. Clin. Cancer Res. 2019, 38, 1-13. [CrossRef]

45. Lukovic, E.; Moitra, V.K.; Freedberg, D.E. The microbiome: Implications for perioperative and critical care. Curr. Opin. Anaesthesiol. 2019, 32, 412-420. [CrossRef]

46. Kageyama, S.; Kadono, K.; Hirao, H.; Nakamura, K.; Ito, T.; Gjertson, D.W.; Sosa, R.A.; Reed, E.F.; Kaldas, F.M.; Busuttil, R.W.; et al. Ischemia-Reperfusion Injury in Allogeneic Liver Transplantation. Transplantation 2020. [CrossRef]

47. Charlton, M.; Levitsky, J.; Aqel, B.; O'Grady, J.; Hemibach, J.; Rinella, M.; Fung, J.; Ghabril, M.; Thomason, R.; Burra, P.; et al. International Liver Transplantation Society Consensus Statement on Immunosuppression in Liver Transplant Recipients. Transplantation 2018, 102, 727-743. [CrossRef]

48. Yoon, Y.I.; Song, G.W.; Lee, S.G.; Hwang, S.; Kim, K.H.; Kim, S.H.; Kang, W.H.; Cho, H.D.; Jwa, E.K.; Kwon, J.H.; et al. Outcome of ABO-incompatible adult living-donor liver transplantation for patients with hepatocellular carcinoma. J. Hepatol. 2018, 68, 1153-1162. [CrossRef]

49. Schubert, K.; Olde Damink, S.W.M.; von Bergen, M.; Schaap, F.G. Interactions between bile salts, gut microbiota, and hepatic innate immunity. Immunol. Rev. 2017, 279, 23-35. [CrossRef]

50. Parséus, A.; Sommer, N.; Sommer, F.; Caesar, R.; Molinaro, A.; Stahlman, M.; Greiner, T.U.; Perkins, R.; Bäckhed, F. Microbiotainduced obesity requires farnesoid $X$ receptor. Gut 2017, 66, 429-437. [CrossRef]

51. Sinal, C.J.; Tohkin, M.; Miyata, M.; Ward, J.M.; Lambert, G.; Gonzalez, F.J. Targeted disruption of the nuclear receptor FXR/BAR impairs bile acid and lipid homeostasis. Cell 2000, 102, 731-744. [CrossRef]

52. Liu, T.; Li, J.; Liu, Y.; Xiao, N.; Suo, H.; Xie, K.; Yang, C.; Wu, C. Short-Chain fatty acids suppress lipopolysaccharide-Induced production of nitric oxide and proinflammatory cytokines through inhibition of NF-кB Pathway in RAW264.7 cells. Inflammation 2012, 35, 1676-1684. [CrossRef] [PubMed]

53. Suriguga, S.; Luangmonkong, T.; Mutsaers, H.A.M.; Groothuis, G.M.M.; Olinga, P. Host microbiota dictates the proinflammatory impact of LPS in the murine liver. Toxicol. Vitr. 2020, 67, 104920. [CrossRef] [PubMed]

54. Jiménez-Castro, M.B.; Cornide-Petronio, M.E.; Gracia-Sancho, J.; Peralta, C. Inflammasome-Mediated Inflammation in Liver Ischemia-Reperfusion Injury. Cells 2019, 8, 1-26. [CrossRef]

55. Zhang, W.; Zhang, J.; Mulholland, M.; Zhang, W. mTOR activation protects liver from ischemia/reperfusion-induced injury through NF-kB pathway. FASEB J. 2017, 31, 3018-3026. [CrossRef]

56. Kim, C.H. Immune regulation by microbiome metabolites. Immunology 2018, 154, 220-229. [CrossRef]

57. Ichikawa, R.; Takayama, T.; Yoneno, K.; Kamada, N.; Kitazume, M.T.; Higuchi, H.; Matsuoka, K.; Watanabe, M.; Itoh, H.; Kanai, T.; et al. Bile acids induce monocyte differentiation toward interleukin-12 hypo-producing dendritic cells via a TGR5-dependent pathway. Immunology 2012, 136, 153-162. [CrossRef]

58. Chávez-talavera, O.; Tailleux, A.; Lefebvre, P.; Staels, B. Bile Acid Control of Metabolism and Inflammation in Obesity, Type 2 Diabetes, Dyslipidemia and NAFLD. Gastroenterology 2017, 152, 1679-1694. [CrossRef]

59. Gulfo, J.; Rotondo, F.; Ávalos de León, C.G.; Cornide-Petronio, M.E.; Fuster, C.; Gracia-Sancho, J.; Jiménez-Castro, M.B.; Peralta, C. FGF15 improves outcomes after brain dead donor liver transplantation with steatotic and non-steatotic grafts in rats. J. Hepatol. 2020, 73, 1131-1143. [CrossRef]

60. León, C.G.A.; Jiménez-Castro, M.B.; Cornide-Petronio, M.E.; Gulfo, J.; Rotondo, F.; Gracia-Sancho, J.; Casillas-Ramírez, A.; Peralta, C. The Effect of Fibroblast Growth Factor 15 Signaling in Non-Steatotic and Steatotic Liver Transplantation from Cardiocirculatory Death. Cells 2019, 8. [CrossRef]

61. Ducastel, S.; Touche, V.; Trabelsi, M.S.; Boulinguiez, A.; Butruille, L.; Nawrot, M.; Peschard, S.; Chávez-Talavera, O.; Dorchies, E.; Vallez, E.; et al. The nuclear receptor FXR inhibits Glucagon-Like Peptide-1 secretion in response to microbiota-derived Short-Chain Fatty Acids. Sci. Rep. 2020, 10, 1-10. [CrossRef] [PubMed]

62. Pathak, P.; Xie, C.; Nichols, R.G.; Ferrell, J.M.; Boehme, S.; Krausz, K.W.; Patterson, A.D.; Gonzalez, F.J.; Chiang, J.Y.L. Intestine farnesoid $X$ receptor agonist and the gut microbiota activate G-protein bile acid receptor-1 signaling to improve metabolism. Hepatology 2018, 68, 1574-1588. [CrossRef] [PubMed] 
63. Avalos-de León, C.G.; Jiménez-Castro, M.B.; Cornide-Petronio, M.E.; Casillas-Ramírez, A.; Peralta, C. The Role of GLP1 in Rat Steatotic and Non-Steatotic Liver Transplantation from Cardiocirculatory Death Donors. Cells 2019, 8, 1-15. [CrossRef] [PubMed]

64. Zhao, L.; Chen, Y.; Xia, F.; Abudukerimu, B.; Zhang, W.; Guo, Y.; Wang, N.; Lu, Y. A glucagon-like peptide-1 receptor agonist lowers weight by modulating the structure of gut microbiota. Front. Endocrinol. (Lausanne) 2018, 9, 1-13. [CrossRef] [PubMed]

65. Psichas, A.; Sleeth, M.L.; Murphy, K.G.; Brooks, L.; Bewick, G.A.; Hanyaloglu, A.C.; Ghatei, M.A.; Bloom, S.R.; Frost, G. The short chain fatty acid propionate stimulates GLP-1 and PYY secretion via free fatty acid receptor 2 in rodents. Int. J. Obes. 2015, 39, 424-429. [CrossRef] [PubMed]

66. Li, M.; van Esch, B.C.A.M.; Wagenaar, G.T.M.; Garssen, J.; Folkerts, G.; Henricks, P.A.J. Pro- and anti-inflammatory effects of short chain fatty acids on immune and endothelial cells. Eur. J. Pharmacol. 2018, 831, 52-59. [CrossRef]

67. Ang, Z.; Er, J.Z.; Tan, N.S.; Lu, J.; Liou, Y.C.; Grosse, J.; Ding, J.L. Human and mouse monocytes display distinct signalling and cytokine profiles upon stimulation with FFAR2/FFAR3 short-chain fatty acid receptor agonists. Sci. Rep. 2016, 6, 1-15. [CrossRef]

68. Qiao, Y.L.; Qian, J.M.; Wang, F.R.; Ma, Z.Y.; Wang, Q.W. Butyrate protects liver against ischemia reperfusion injury by inhibiting nuclear factor kappa B activation in Kupffer cells. J. Surg. Res. 2014, 187, 653-659. [CrossRef]

69. Corrêa-Oliveira, R.; Fachi, J.L.; Vieira, A.; Sato, F.T.; Vinolo, M.A.R. Regulation of immune cell function by short-chain fatty acids. Clin. Transl. Immunol. 2016, 5, 1-8. [CrossRef]

70. Asarat, M.; Apostolopoulos, V.; Vasiljevic, T.; Donkor, O. Short-chain fatty acids regulate cytokines and Th17/treg cells in human peripheral blood mononuclear cells in vitro. Immunol. Invest. 2016, 45, 205-222. [CrossRef]

71. Clavien, P.A.; Muller, X.; de Oliveira, M.L.; Dutkowski, P.; Sanchez-Fueyo, A. Can immunosuppression be stopped after liver transplantation? Lancet Gastroenterol. Hepatol. 2017, 2, 531-537. [CrossRef]

72. Wu, Z.W.; Ling, Z.X.; Lu, H.F.; Zuo, J.; Sheng, J.F.; Zheng, S.S.; Li, L.J. Changes of gut bacteria and immune parameters in liver transplant recipients. Hepatobiliary Pancreat. Dis. Int. 2012, 11, 40-50. [CrossRef]

73. Buchman, A.L. Glutamine: Is it a conditionally required nutrient for the human gastrointestinal system? J. Am. Coll. Nutr. 1996, 15, 199-205. [CrossRef] [PubMed]

74. Kim, M.H.; Kim, H. The roles of glutamine in the intestine and its implication in intestinal diseases. Int. J. Mol. Sci. 2017, 18. [CrossRef] [PubMed]

75. Cruzat, V.; Rogero, M.M.; Keane, K.N.; Curi, R.; Newsholme, P. Glutamine: Metabolism and immune function, supplementation and clinical translation. Nutrients 2018, 10, 1-31. [CrossRef]

76. Hammad, A.; Kaido, T.; Aliyev, V.; Mandato, C.; Uemoto, S. Nutritional therapy in liver transplantation. Nutrients 2017, 9 , 1-25. [CrossRef]

77. Mu, J.; Chen, Q.; Zhu, L.; Wu, Y.; Liu, S.; Zhao, Y.; Ma, T. Influence of gut microbiota and intestinal barrier on enterogenic infection after liver transplantation. Curr. Med. Res. Opin. 2019, 35, 241-248. [CrossRef]

78. Portune, K.J.; Beaumont, M.; Davila, A.M.; Tomé, D.; Blachier, F.; Sanz, Y. Gut microbiota role in dietary protein metabolism and health-related outcomes: The two sides of the coin. Trends Food Sci. Technol. 2016, 57, 213-232. [CrossRef]

79. Echániz, A.; Pita, S.; Otero, A.; Suárez, F.; Gómez, M.; Guerrero, A. Incidencia, factores de riesgo e influencia sobre la supervivencia de las complicaciones infecciosas en el trasplante hepático. Enferm. Infecc. Microbiol. Clin. 2003, 21, 224-231. [CrossRef]

80. Losada, I.; Cuervas-Mons, V.; Millán, I.; Dámaso, D. Early infection in liver transplant recipients: Incidence, severity, risk factors and antibiotic sensitivity of bacterial isolate. Enferm. Infecc. Microbiol. Clin. 2002, 20, 422-430. [CrossRef]

81. Kato, K.; Nagao, M.; Miyamoto, K.; Oka, K.; Takahashi, M.; Yamamoto, M.; Matsumura, Y.; Kaido, T.; Uemoto, S.; Ichiyama, S. Longitudinal Analysis of the Intestinal Microbiota in Liver Transplantation. Transplant. Direct. 2017, 3, e144. [CrossRef] [PubMed]

82. Nicoletti, A.; Ponziani, F.R.; Biolato, M.; Valenza, V.; Marrone, G.; Sganga, G.; Gasbarrini, A.; Miele, L.; Grieco, A. Intestinal permeability in the pathogenesis of liver damage: From non-alcoholic fatty liver disease to liver transplantation. World J. Gastroenterol. 2019, 25, 4814-4834. [CrossRef] [PubMed]

83. Xie, Y.R.; Liu, S.L.; Liu, X.; Luo, Z.B.; Zhu, B.; Li, Z.F.; Li, L.J.; He, Y.; Jiang, L.; Li, H.; et al. Intestinal microbiota and innate immunity-related gene alteration in cirrhotic rats with liver transplantation. Transplant. Proc. 2011, 43, 3973-3979. [CrossRef] [PubMed]

84. Xie, Y.; Luo, Z.; Li, Z.; Deng, M.; Liu, H.; Zhu, B.; Ruan, B.; Li, L. Structural Shifts of Fecal Microbial Communities in Rats with Acute Rejection after Liver Transplantation. Microb. Ecol. 2012, 64, 546-554. [CrossRef] [PubMed]

85. Ren, Z.; Jiang, J.; Lu, H.; Chen, X.; He, Y.; Zhang, H.; Xie, H.; Wang, W.; Zheng, S.; Zhou, L. Intestinal microbial variation may predict early acute rejection after liver transplantation in rats. Transplantation 2014, 98, 844-852. [CrossRef] [PubMed]

86. Xie, Y.; Chen, H.; Zhu, B.; Qin, N.; Chen, Y.; Li, Z.; Deng, M.; Jiang, H.; Xu, X.; Yang, J.; et al. Effect of Intestinal Microbiota Alteration on Hepatic Damage in Rats with Acute Rejection After Liver Transplantation. Microb. Ecol. 2014, 68, 871-880. [CrossRef] [PubMed]

87. Fernández, L.; Heredia, N.; Peralta, C.; Xaus, C.; Roselló-Catafau, J.; Rimola, A.; Marco, A.; Serafín, A.; Deulofeu, R.; Gelpí, E.; et al. Role of ischemic preconditioning and the portosystemic shunt in the prevention of liver and lung damage after rat liver transplantation. Transplantation 2003, 76, 282-289. [CrossRef]

88. Mendes-Braz, M.; Elias-Miró, M.; Jiménez-Castro, M.B.; Casillas-Ramírez, A.; Ramalho, F.S.; Peralta, C. The current state of knowledge of hepatic ischemia-reperfusion injury based on its study in experimental models. J. Biomed. Biotechnol. 2012, 2012. [CrossRef] 
89. Casillas-Ramírez, A.; Mosbah, I.B.; Ramalho, F.; Roselló-Catafau, J.; Peralta, C. Past and future approaches to ischemia-reperfusion lesion associated with liver transplantation. Life Sci. 2006, 79, 1881-1894. [CrossRef]

90. Jiménez-Castro, M.B.; Meroño, N.; Mendes-Braz, M.; Gracia-Sancho, J.; Martínez-Carreres, L.; Cornide-Petronio, M.E.; CasillasRamirez, A.; Rodés, J.; Peralta, C. The effect of brain death in rat steatotic and non-steatotic liver transplantation with previous ischemic preconditioning. J. Hepatol. 2015, 62, 83-91. [CrossRef]

91. Fernández, L.; Carrasco-Chaumel, E.; Serafín, A.; Xaus, C.; Grande, L.; Rimola, A.; Roselló-Catafau, J.; Peralta, C. Is ischemic preconditioning a useful strategy in steatotic liver transplantation? Am. J. Transplant. 2004, 4, 888-899. [CrossRef] [PubMed]

92. Schlegel, A.; Scalera, I.; Perera, M.T.P.R.; Kalisvaart, M.; Mergental, H.; Mirza, D.F.; Isaac, J.; Muiesan, P. Impact of donor age in donation after circulatory death liver transplantation: Is the cutoff "60" still of relevance? Liver Transplant. 2018, 24, 352-362. [CrossRef] [PubMed]

93. Pan, E.T.; Yoeli, D.; Galvan, N.T.N.; Kueht, M.L.; Cotton, R.T.; O’Mahony, C.A.; Goss, J.A.; Rana, A. Cold ischemia time is an important risk factor for post-liver transplant prolonged length of stay. Liver Transplant. 2018, 24, 762-768. [CrossRef] [PubMed]

94. Son, Y.G.; Lee, H.; Oh, S.Y.; Jung, C.W.; Ryu, H.G. Risk Factors for Intensive Care Unit Readmission After Liver Transplantation: A Retrospective Cohort Study. Ann. Transplant. 2018, 23, 767-774. [CrossRef] [PubMed]

95. Lu, H.; He, J.; Wu, Z.; Xu, W.; Zhang, H.; Ye, P.; Yang, J.; Zhen, S.; Li, L. Assessment of Microbiome Variation During the Perioperative Period in Liver Transplant Patients: A Retrospective Analysis. Microb. Ecol. 2013, 65, 781-791. [CrossRef] [PubMed]

96. Bajaj, J.S.; Fagan, A.; Sikaroodi, M.; White, M.B.; Sterling, R.K.; Gilles, H.C.; Heuman, D.; Stravitz, R.T.; Matherly, S.C.; Siddiqui, M.S.; et al. Liver transplant modulates gut microbial dysbiosis and cognitive function in cirrhosis. Liver Transplant. 2017, 23, 907-914. [CrossRef]

97. Sun, L.Y.; Yang, Y.S.; Qu, W.; Zhu, Z.J.; Wei, L.; Ye, Z.S.; Zhang, J.R.; Sun, X.Y.; Zeng, Z.G. Gut microbiota of liver transplantation recipients. Sci. Rep. 2017, 7, 1-10. [CrossRef]

98. Tourret, J.; Willing, B.P.; Dion, S.; MacPherson, J.; Denamur, E.; Finlay, B.B. Immunosuppressive treatment alters secretion of ileal antimicrobial peptides and gut microbiota, and favors subsequent colonization by uropathogenic Escherichia coli. Transplantation 2017, 101, 74-82. [CrossRef]

99. Jia, J.; Tian, X.; Jiang, J.; Ren, Z.; Lu, H.; He, N.; Xie, H.; Zhou, L.; Zheng, S. Structural shifts in the intestinal microbiota of rats treated with cyclosporine A after orthotropic liver transplantation. Front. Med. 2019, 13, 451-460. [CrossRef]

100. Jiang, J.W.; Ren, Z.G.; Lu, H.F.; Zhang, H.; Li, A.; Cui, G.Y.; Jia, J.J.; Xie, H.Y.; Chen, X.H.; He, Y.; et al. Optimal immunosuppressor induces stable gut microbiota after liver transplantation. World J. Gastroenterol. 2018, 24, 3871-3883. [CrossRef]

101. Gabe, S.M.; Bjarnason, I.; Tolou-Ghamari, Z.; Tredger, J.M.; Johnson, P.G.; Barclay, G.R.; Williams, R.; Silk, D.B.A. The effect of tacrolimus (FK506) on intestinal barrier function and cellular energy production in humans. Gastroenterology 1998, 115, 67-74. [CrossRef]

102. Parrilli, G.; Abazia, C.; Sarnelli, G.; Corsaro, M.M.; Coccoli, P.; Viglione, L.; Cuomo, R.; Budillon, G. Effect of chronic administration of tacrolimus and cyclosporine on human gastrointestinal permeability. Liver Transplant. 2003, 9, 484-488. [CrossRef] [PubMed]

103. Ladirat, S.E.; Schols, H.A.; Nauta, A.; Schoterman, M.H.C.; Keijser, B.J.F.; Montijn, R.C.; Gruppen, H.; Schuren, F.H.J. Highthroughput analysis of the impact of antibiotics on the human intestinal microbiota composition. J. Microbiol. Methods 2013, 92, 387-397. [CrossRef] [PubMed]

104. Tanim Anwar, A.S.M.; Lee, J.M. Medical management of brain-dead organ donors. Acute Crit. Care 2019, 34, 14-29. [CrossRef]

105. Xiao, J.; Peng, Z.; Liao, Y.; Sun, H.; Chen, W.; Chen, X.; Wei, Z.; Yang, C.; Nüssler, A.K.; Liu, J.; et al. Organ transplantation and gut microbiota: Current reviews and future challenges. Am. J. Transl. Res. 2018, 10, 3330-3344. [PubMed]

106. Zieve, L.; Shekleton, M.; Lyftogt, C.; Draves, K. Ammonia, octanoate and a mercaptan depress regeneration of normal rat liver after partial hepatectomy. Hepatology 1985, 5, 28-31. [CrossRef]

107. Michalopoulos, G.K. Advances in liver regeneration. Expert Rev. Gastroenterol. Hepatol. 2014, 8, 897-907. [CrossRef]

108. Liu, H.-X.; Keane, R.; Sheng, L.; Wan, Y.-J.Y. Implications of microbiota and bile acid in liver injury and regeneration. J. Hepatol. 2015, 63, 1502-1510. [CrossRef]

109. Liu, H.X.; Hu, Y.; Wan, Y.J.Y. Microbiota and bile acid profiles in retinoic acid-primed mice that exhibit accelerated liver regeneration. Oncotarget 2016, 7, 1096-1106. [CrossRef]

110. Nardone, G.; Compare, D.; Liguori, E.; Di Mauro, V.; Rocco, A.; Barone, M.; Napoli, A.; Lapi, D.; Iovene, M.R.; Colantuoni, A. Protective effects of Lactobacillus paracasei F19 in a rat model of oxidative and metabolic hepatic injury. Am. J. Physiol. Gastrointest. Liver Physiol. 2010, 299, 669-676. [CrossRef]

111. McCormack, L.; Petrowsky, H.; Jochum, W.; Furrer, K.; Clavien, P.A. Hepatic steatosis is a risk factor for postoperative complications after major hepatectomy: A matched case-control study. Ann. Surg. 2007, 245, 923-930. [CrossRef] [PubMed]

112. Xing, H.-c.; Li, L.-j.; Xu, K.-j.; Shen, T.; Chen, Y.-b.; Sheng, J.-f.; Yu, Y.-s.; Chen, Y.-g. Intestinal microflora in rats with ischemia/reperfusion liver injury. J. Zhejiang Univ. Sci. B. 2005, 6, 14-21. [CrossRef] [PubMed]

113. Cornell, R.P.; Liljequist, B.L.; Bartizal, K.F. Depressed liver regeneration after partial hepatectomy of germ-free, athymic and lipopolysaccharide-resistant mice. Hepatology 1990, 11, 916-922. [CrossRef] [PubMed]

114. Liu, H.X.; Hu, Y.; French, S.W.; Gonzalez, F.J.; Wan, Y.J.Y. Forced expression of fibroblast growth factor 21 reverses the sustained impairment of liver regeneration in PPAR $\alpha$ PAC mice due to dysregulated bile acid synthesis. Oncotarget 2015, 6, 9686-9700. [CrossRef] [PubMed] 
115. Gart, E.; Lima, E.S.; Schuren, F.; de Ruiter, C.G.F.; Attema, J.; Verschuren, L.; Keijer, J.; Salic, K.; Morrison, M.C.; Kleemann, R. Diet-independent correlations between bacteria and dysfunction of gut, adipose tissue, and liver: A comprehensive microbiota analysis in feces and mucosa of the ileum and colon in obese mice with NAFLD. Int. J. Mol. Sci. 2019, 20, 1-20. [CrossRef] [PubMed]

116. He, J.; Zhang, P.; Shen, L.; Niu, L.; Tan, Y.; Chen, L.; Zhao, Y.; Bai, L.; Hao, X.; Li, X.; et al. Short-chain fatty acids and their association with signalling pathways in inflammation, glucose and lipid metabolism. Int. J. Mol. Sci. 2020, 21, 1-16. [CrossRef]

117. Hoffmann, K.; Büchler, M.W.; Schemmer, P. Supplementation of amino acids to prevent reperfusion injury after liver surgery and transplantation-Where do we stand today? Clin. Nutr. 2011, 30, 143-147. [CrossRef]

118. Ardito, F.; Lai, Q.; Rinninella, E.; Mimmo, A.; Vellone, M.; Panettieri, E.; Adducci, E.; Cintoni, M.; Mele, M.C.; Gasbarrini, A.; et al. The impact of personalized nutritional support on postoperative outcome within the enhanced recovery after surgery (ERAS) program for liver resections: Results from the NutriCatt protocol. Updates Surg. 2020, 72, 681-691. [CrossRef]

119. Okabayashi, T.; Nishimori, I.; Sugimoto, T.; Maeda, H.; Dabanaka, K.; Onishi, S.; Kobayashi, M.; Hanazaki, K. Effects of branchedchain amino acids-enriched nutrient support for patients undergoing liver resection for hepatocellular carcinoma. J. Gastroenterol. Hepatol. 2008, 23, 1869-1873. [CrossRef]

120. Lin, R.; Liu, W.; Piao, M.; Zhu, H. A review of the relationship between the gut microbiota and amino acid metabolism. Amino Acids 2017, 49, 2083-2090. [CrossRef]

121. Gutiérrez-Repiso, C.; Moreno-indias, I.; de Hollanda, A.; Martín-núñez, G.M.; Vidal, J.; Tinahones, F.J. Gut microbiota specific signatures are related to the successful rate of bariatric surgery. Am. J. Transl. Res. 2019, 11, 942-952. [PubMed]

122. Aron-Wisnewsky, J.; Clement, K. The Effects of Gastrointestinal Surgery on Gut Microbiota: Potential Contribution to Improved Insulin Sensitivity. Curr. Atheroscler. Rep. 2014, 16, 1-11. [CrossRef] [PubMed]

123. Mardinoglu, A.; Heiker, J.T.; Gärtner, D.; Björnson, E.; Schön, M.R.; Flehmig, G.; Klöting, N.; Krohn, K.; Fasshauer, M.; Stumvoll, M.; et al. Extensive weight loss reveals distinct gene expression changes in human subcutaneous and visceral adipose tissue. Sci. Rep. 2015, 5, 1-11. [CrossRef] [PubMed]

124. Ito, A.; Higashiguchi, T. Effects of glutamine administration on liver regeneration following hepatectomy. Nutrition 1999, 15, 23-28. [CrossRef]

125. Magalhães, C.R.; Malafaia, O.; Torres, O.J.M.; Moreira, L.B.; Tefil, S.C.d.S.G.; Pinherio, M.d.R.; Harada, B.A. Liver regeneration with l-glutamine supplemented diet: Experimental study in rats. Rev. Col. Bras. Cir. 2014, 41, 117-121. [CrossRef] [PubMed]

126. Jacobs, J.P.; Dong, T.S.; Agopian, V.; Lagishetty, V.; Sundaram, V.; Noureddin, M.; Ayoub, W.S.; Durazo, F.; Benhammou, J.; Enayati, P.; et al. Microbiome and bile acid profiles in duodenal aspirates from patients with liver cirrhosis: The Microbiome, Microbial Markers and Liver Disease Study. Hepatol. Res. 2018, 48, 1108-1117. [CrossRef]

127. Duytschaever, G.; Huys, G.; Bekaert, M.; Boulanger, L.; De Boeck, K.; Vandamme, P. Dysbiosis of bifidobacteria and Clostridium cluster XIVa in the cystic fibrosis fecal microbiota. J. Cyst. Fibros. 2013, 12, 206-215. [CrossRef]

128. Cuenca, S.; Sanchez, E.; Santiago, A.; El Khader, I.; Panda, S.; Vidal, S.; Nieto, J.C.; Juárez, C.; Sancho, F.; Guarner, F.; et al. Microbiome composition by pyrosequencing in mesenteric lymph nodes of rats with CCl4-induced cirrhosis. J. Innate Immun. 2014, 6, 263-271. [CrossRef]

129. Soto, G.; Rodríguez, M.J.; Fuentealba, R.; Treuer, A.V.; Castillo, I.; González, D.R.; Zúñiga-Hernández, J. Maresin 1, a proresolving lipid mediator, ameliorates liver ischemia-reperfusion injury and stimulates hepatocyte proliferation in sprague-dawley rats. Int. J. Mol. Sci. 2020, 21. [CrossRef]

130. Wu, X.; Sun, R.; Chen, Y.; Zheng, X.; Bai, L.; Lian, Z.; Wei, H.; Tian, Z. Oral Ampicillin Inhibits Liver Regeneration by Breaking Hepatic Innate Immune Tolerance Normally Maintained by Gut Commensal Bacteria. Hepatology 2015, 62, 253-264. [CrossRef]

131. Ling, J.; Chaba, T.; Zhu, L.F.; Jacobs, R.L.; Vance, D.E. Hepatic ratio of phosphatidylcholine to phosphatidylethanolamine predicts survival after partial hepatectomy in mice. Hepatology 2012, 55, 1094-1102. [CrossRef] [PubMed]

132. Kolodziejczyk, A.A.; Zheng, D.; Shibolet, O.; Elinav, E. The role of the microbiome in NAFLD and NASH. EMBO Mol. Med. 2019, 11, 1-13. [CrossRef] [PubMed]

133. Kakiyama, G.; Pandak, W.M.; Gillevet, P.M.; Hylemon, P.B.; Heuman, D.M.; Daita, K.; Takei, H.; Muto, A.; Nittono, H.; Ridlon, J.M.; et al. Modulation of the fecal bile acid profile by gut microbiota in cirrhosis. J. Hepatol. 2013, 58, 949-955. [CrossRef] [PubMed]

134. Chen, J.; Vitetta, L. Gut microbiota metabolites in nafld pathogenesis and therapeutic implications. Int. J. Mol. Sci. 2020, 21, 1-19. [CrossRef] [PubMed]

135. Yu, Y.; Raka, F.; Adeli, K. The Role of the Gut Microbiota in Lipid and Lipoprotein Metabolism. J. Clin. Med. 2019, 8, 2227. [CrossRef] [PubMed]

136. Sittipo, P.; Shim, J.W.; Lee, Y.K. Microbial metabolites determine host health and the status of some diseases. Int. J. Mol. Sci. 2019, 20. [CrossRef]

137. Doycheva, I.; Leise, M.D.; Watt, K.D. The intestinal microbiome and the liver transplant recipient: What we know and what we need to know. Transplantation 2016, 100, 61-68. [CrossRef]

138. Xing, H.C.; Li, L.J.; Xu, K.J.; Shen, T.; Chen, Y.B.; Sheng, J.F.; Chen, Y.; Fu, S.Z.; Chen, C.L.; Wang, J.G.; et al. Protective role of supplement with foreign Bifidobacterium and Lactobacillus in experimental hepatic ischemia-reperfusion injury. J. Gastroenterol. Hepatol. 2006, 21, 647-656. [CrossRef]

139. Ren, Z.; Cui, G.; Lu, H.; Chen, X.; Jiang, J.; Liu, H.; He, Y.; Ding, S.; Hu, Z.; Wang, W.; et al. Liver Ischemic Preconditioning (IPC) Improves Intestinal Microbiota Following Liver Transplantation in Rats through 16s rDNA-Based Analysis of Microbial Structure Shift. PLoS ONE 2013, 8, 1-12. [CrossRef] 
140. Koh, W.U.; Kim, J.; Lee, J.; Song, G.W.; Hwang, G.S.; Tak, E.; Song, J.G. Remote ischemic preconditioning and diazoxide protect from hepatic ischemic reperfusion injury by inhibiting HMGB1-induced TLR4/MyD88/NF-kB signaling. Int. J. Mol. Sci. 2019, 20. [CrossRef]

141. Sawas, T.; Al Halabi, S.; Hernaez, R.; Carey, W.D.; Cho, W.K. Patients Receiving Prebiotics and Probiotics Before Liver Transplantation Develop Fewer Infections Than Controls: A Systematic Review and Meta-Analysis. Clin. Gastroenterol. Hepatol. 2015, 13, 1567-1574.e3. [CrossRef] [PubMed]

142. Wiest, R.; Albillos, A.; Trauner, M.; Bajaj, J.S.; Jalan, R. Targeting the gut-liver axis in liver disease. J. Hepatol. 2017, 67, 1084-1103. [CrossRef] [PubMed]

143. Shen, T.C.D.; Pyrsopoulos, N.; Rustgi, V.K. Microbiota and the liver. Liver Transplant. 2018, 24, 539-550. [CrossRef] [PubMed]

144. Zhang, Y.; Chen, J.; Wu, J.; Chalson, H.; Merigan, L.; Mitchell, A. Probiotic use in preventing postoperative infection in liver transplant patients. Hepatobiliary Surg. Nutr. 2013, 2, 142-147. [CrossRef]

145. Rayes, N.; Seehofer, D.; Hansen, S.; Boucsein, K.; Müller, A.R.; Serke, S.; Bengmark, S.; Neuhaus, P. Early enteral supply of Lactobacillus and fiber versus selective bowel decontamination: A controlled trial in liver transplant recipients. Transplantation 2002, 74, 123-128. [CrossRef]

146. Rayes, N.; Seehofer, D.; Theruvath, T.; Schiller, R.A.; Langrehr, J.M.; Jonas, S.; Bengmark, S.; Neuhaus, P. Supply of pre- and probiotics reduces bacterial infection rates after liver transplantation-A randomized, double-blind trial. Am. J. Transplant. 2005, 5, 125-130. [CrossRef]

147. Arai, M.; Mochida, S.; Ohno, A.; Arai, S.; Fujiwara, K. Selective bowel decontamination of recipients for prevention against liver injury following orthotopic liver transplantation: Evaluation with rat models. Hepatology 1998, 27, 123-127. [CrossRef]

148. Sun, H.Y.; Wagener, M.; Cacciarelli, T.V.; Singh, N. Impact of rifaximin use for hepatic encephalopathy on the risk of early post-transplant infections in liver transplant recipients. Clin. Transplant. 2012, 26, 849-852. [CrossRef]

149. Nakamura, K.; Kageyama, S.; Ito, T.; Hirao, H.; Kadono, K.; Aziz, A.; Dery, K.J.; Everly, M.J.; Taura, K.; Uemoto, S.; et al. Antibiotic pretreatment alleviates liver transplant damage in mice and humans. J. Clin. Invest. 2019, 129, 3420-3434. [CrossRef]

150. Hellinger, W.C.; Yao, J.D.; Alvarez, S.; Blair, J.E.; Cawley, J.J.; Paya, C.V.; O’Brien, P.C.; Spivey, J.R.; Dickson, R.C.; Harnois, D.M.; et al. A randomized, prospective, double-blinded evaluation of selective bowel decontamination in liver transplantation. Transplantation 2002, 73, 1904-1909. [CrossRef]

151. Annavajhala, M.K.; Gomez-Simmonds, A.; Macesic, N.; Sullivan, S.B.; Kress, A.; Khan, S.D.; Giddins, M.J.; Stump, S.; Kim, G.I.; Narain, R.; et al. Colonizing multidrug-resistant bacteria and the longitudinal evolution of the intestinal microbiome after liver transplantation. Nat. Commun. 2019, 10. [CrossRef] [PubMed]

152. Qin, J.; Zhou, J.; Dai, X.; Zhou, H.; Pan, X.; Wang, X.; Zhang, F.; Rao, J.; Lu, L. Short-term starvation attenuates liver ischemiareperfusion injury (IRI) by sirt1-autophagy signaling in mice. Am. J. Transl. Res. 2016, 8, 3364-3375. [PubMed]

153. Rickenbacher, A.; Jang, J.H.; Limani, P.; Ungethüm, U.; Lehmann, K.; Oberkofler, C.E.; Weber, A.; Graf, R.; Humar, B.; Clavien, P.A. Fasting protects liver from ischemic injury through Sirt1-mediated downregulation of circulating HMGB1 in mice. J. Hepatol. 2014, 61, 301-308. [CrossRef] [PubMed]

154. Zhan, C.; Dai, X.; Shen, G.; Lu, X.; Wang, X.; Lu, L.; Qian, X.; Rao, J. Preoperative short-term fasting protects liver injury in patients undergoing hepatectomy. Ann. Transl. Med. 2018, 6, 449. [CrossRef]

155. Page, A.J.; Ejaz, A.; Spolverato, G.; Zavadsky, T.; Grant, M.C.; Galante, D.J.; Wick, E.C.; Weiss, M.; Makary, M.A.; Wu, C.L.; et al. Enhanced Recovery After Surgery Protocols for Open Hepatectomy-Physiology, Immunomodulation, and Implementation. J. Gastrointest. Surg. 2015, 19, 387-399. [CrossRef]

156. Zaborin, A.; Penalver Bernabe, B.; Keskey, R.; Sangwan, N.; Hyoju, S.; Gottel, N.; Gilbert, J.A.; Zaborina, O.; Alverdy, J.C. Spatial Compartmentalization of the Microbiome between the Lumen and Crypts Is Lost in the Murine Cecum following the Process of Surgery, Including Overnight Fasting and Exposure to Antibiotics. mSystems 2020, 5. [CrossRef]

157. Caraceni, P.; Nardo, B.; Domenicali, M.; Turi, P.; Vici, M.; Simoncini, M.; De Maria, N.; Trevisani, F.; Van Thiel, D.H.; Derenzini, M.; et al. Ischemia-reperfusion injury in rat fatty liver: Role of nutritional status. Hepatology 1999, 29, 1139-1146. [CrossRef]

158. Ren, J.; Hu, D.; Mao, Y.; Yang, H.; Liao, W.; Xu, W.; Ge, P.; Zhang, H.; Sang, X.; Lu, X.; et al. Alteration in gut microbiota caused by time-restricted feeding alleviate hepatic ischaemia reperfusion injury in mice. J. Cell. Mol. Med. 2019, 23, 1714-1722. [CrossRef]

159. Melkani, G.C.; Panda, S. Time-restricted feeding for prevention and treatment of cardiometabolic disorders. J. Physiol. 2017, 595, 3691-3700. [CrossRef]

160. Ren, Z.G.; Liu, H.; Jiang, J.W.; Jiang, L.; Chen, H.; Xie, H.Y.; Zhou, L.; Zheng, S. Sen Protective effect of probiotics on intestinal barrier function in malnourished rats after liver transplantation. Hepatobiliary Pancreat. Dis. Int. 2011, 10, 489-496. [CrossRef]

161. Kamo, N.; Kaido, T.; Hamaguchi, Y.; Uozumi, R.; Okumura, S.; Kobayashi, A.; Shirai, H.; Yagi, S.; Okajima, H.; Uemoto, S. Impact of Enteral Nutrition with an Immunomodulating Diet Enriched with Hydrolyzed Whey Peptide on Infection After Liver Transplantation. World J. Surg. 2018, 42, 3715-3725. [CrossRef] [PubMed]

162. Shu, X.L.; Yu, T.T.; Zhong, J.X.; Lei, T. Effect of glutamine on intestinal barrier function following liver transplantation in rats. Eur. Rev. Med. Pharmacol. Sci. 2014, 18, 2058-2064. [PubMed]

163. Rayes, N.; Pilarski, T.; Stockmann, M.; Bengmark, S.; Neuhaus, P.; Seehofer, D. Effect of pre- and probiotics on liver regeneration after resection: A randomised, double-blind pilot study. Benef. Microbes 2012, 3, 237-244. [CrossRef] [PubMed]

164. Rifatbegovic, Z.; Mesic, D.; Ljuca, F.; Zildzic, M.; Avdagic, M.; Grbic, K.; Agic, M.; Hadziefendic, B. Effect of probiotics on liver function after surgery resection for malignancy in the liver cirrhotic. Med. Arh. 2010, 64, 208-211. [PubMed] 
165. Gan, Y.; Su, S.; Li, B.; Fang, C. Efficacy of probiotics and prebiotics in prevention of infectious complications following hepatic resections: Systematic review and meta-analysis. J. Gastrointest. Liver Dis. 2019, 28, 205-211. [CrossRef]

166. Mendes-Braz, M.; Elias-Miró, M.; Kleuser, B.; Fayyaz, S.; Jiménez-Castro, M.B.; Massip-Salcedo, M.; Gracia-Sancho, J.; Ramalho, F.S.; Rodes, J.; Peralta, C. The effects of glucose and lipids in steatotic and non-steatotic livers in conditions of partial hepatectomy under ischaemia-reperfusion. Liver Int. 2014, 34, 271-289. [CrossRef]

167. Yang, Y.; Shao, C.; Zhang, W.; Wang, G.; Lu, D.C.; Han, W.; Wu, Z.S.; Chen, C.B. Omega-3 polyunsaturated fatty acids prevent progression of liver fibrosis and promote liver regeneration after partial hepatectomy in cirrhotic rats. Eur. Rev. Med. Pharmacol. Sci. 2019, 23, 10151-10160. [CrossRef]

168. Beppu, T.; Nitta, H.; Hayashi, H.; Imai, K.; Okabe, H.; Nakagawa, S.; Hashimoto, D.; Chikamoto, A.; Ishiko, T.; Yoshida, M.; et al. Effect of branched-chain amino acid supplementation on functional liver regeneration in patients undergoing portal vein embolization and sequential hepatectomy: A randomized controlled trial. J. Gastroenterol. 2015, 50, 1197-1205. [CrossRef]

169. Nanno, Y.; Toyama, H.; Terai, S.; Mizumoto, T.; Tanaka, M.; Kido, M.; Ajiki, T.; Fukumoto, T. Preoperative Oral Branched-Chain Amino Acid Supplementation Suppresses Intraoperative and Postoperative Blood Lactate Levels in Patients Undergoing Major Hepatectomy. J. Parenter Enter. Nutr. 2019, 43, 220-225. [CrossRef]

170. Ucar, M.; Aydogan, M.S.; Vardı, N.; Parlakpınar, H. Protective Effect of Dexpanthenol on Ischemia-Reperfusion-Induced Liver Injury. Transplant. Proc. 2018, 50, 3135-3143. [CrossRef]

171. Shama, S.; Liu, W. Omega-3 Fatty Acids and Gut Microbiota: A Reciprocal Interaction in Nonalcoholic Fatty Liver Disease. Dig. Dis. Sci. 2020, 65, 906-910. [CrossRef] [PubMed]

172. Wang, Z.; Zhang, X.; Zhu, L.; Yang, X.; He, F.; Wang, T.; Bao, T.; Lu, H.; Wang, H.; Yang, S. Inulin alleviates inflammation of alcoholic liver disease via SCFAs-inducing suppression of M1 and facilitation of M2 macrophages in mice. Int. Immunopharmacol. 2020, 78, 106062. [CrossRef] [PubMed]

173. Zambom de Souza, A.Z.; Zambom, A.Z.; Abboud, K.Y.; Reis, S.K.; Tannihão, F.; Guadagnini, D.; Saad, M.J.A.; Prada, P.O. Oral supplementation with l-glutamine alters gut microbiota of obese and overweight adults: A pilot study. Nutrition 2015, 31, 884-889. [CrossRef] [PubMed] 